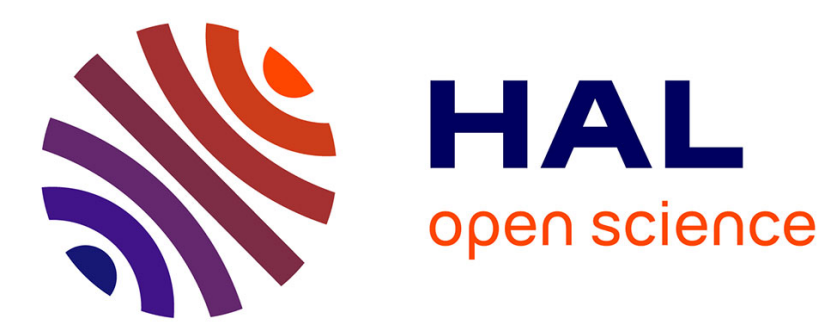

\title{
The Critical Success Factors Of The ERP System Project: A Meta-Analysis Methodology
}

Abdesamad Zouine, Pierre Fenies

\section{To cite this version:}

Abdesamad Zouine, Pierre Fenies. The Critical Success Factors Of The ERP System Project: A Meta-Analysis Methodology. Journal of Applied Business Research, 2014, 30, pp.1407-1447. 10.19030/jabr.v30i5.8796 . hal-01419785

\section{HAL Id: hal-01419785 \\ https://hal.science/hal-01419785}

Submitted on 19 Dec 2016

HAL is a multi-disciplinary open access archive for the deposit and dissemination of scientific research documents, whether they are published or not. The documents may come from teaching and research institutions in France or abroad, or from public or private research centers.
L'archive ouverte pluridisciplinaire HAL, est destinée au dépôt et à la diffusion de documents scientifiques de niveau recherche, publiés ou non, émanant des établissements d'enseignement et de recherche français ou étrangers, des laboratoires publics ou privés. 


\title{
The Critical Success Factors Of The ERP System Project: A Meta-Analysis Methodology \\ Abdesamad Zouine, CRCGM, France Pierre Fenies, CEROS, France
}

\begin{abstract}
Many articles have been written on enterprise resource planning success in the last two decades in both the public and private sector. An important number of empirical studies attempt to delineate the steps of ERP project integration and their specificities. These research works can be divided into two principal phases: the implementation and the post-implementation. The complex nature of the ERP system and its implementation stages lead us to investigate about the critical success factors mentioned in both phases of integration. Recently, several studies have tried to assess the success of ERP system and highlight the CSF's based on some theoretical models. This study uses a meta-analysis methodology to highlight the principal factors leading to ERP success, and it evaluates the weight of CSF's in the process of implementing the ERP project. Based on the best studies published in the last years about ERP success, we conduct this research to determine the most important factors highly correlated with the ERP success. Eleven CSF's are identified in our meta-analysis and classified according to their significant importance based on the correlation coefficients finding in 32 articles focus only on the ERP system. Some criteria were selected to choose studies such as: Sample size, the availability of correlation coefficient finding (quantitative empirical data), the availability of reliable constructs (Cronbach's alpha), and the measurement scale of each factor.
\end{abstract}

Keywords: ERP System; Meta-Analysis; Performance; Critical Success Factors

\section{INTRODUCTION}

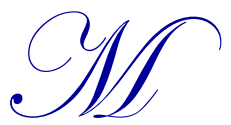

ore than 20 years ago, one of the most important information systems software appeared; the beginning of the 90's was characterized by the emergence of ERP system, ${ }^{1}$ considered as a strategic weapon for many companies around the world. The investment in this kind of project is under increasing scrutiny and pressure to justify their value and contribution to the performance, quality, and competitiveness of organizations (Gable et al., 2003). Currently, and after approximately two decades, all the largest business companies are now equipped with the ERP system in order to follow the environment change and business development. The integration of this project is considered as one of the most important challenges for the top management, project manager, ERP consultant, and vendor at different levels of the organization, to be able to maximize its appropriation. The ERP integration requires large investment, and it is associated with many problems in the implementation phase (Markus \& Tanis, 2000). Despite the substantial investments made by organizations, its success had been minor (Davenport, 1998; Davis, 1989b; Gable et al., 2003; Sedera \& Gable, 2010). In the literature review, many theoretical researches attempt to develop models to evaluate the information systems success. However, these models are not entirely appropriate for measuring ERP system success (Gable et al., 2003) for many reasons such as its specificities, characteristics, and complexity of implementation. The organization must support and manage the change introduced by the ERP system, because its integration needs an important reorganization and transformation in the business process, at both strategic and technical level. In many cases, this resistance is

${ }^{1}$ ERP System: Enterprise Resource Planning is defined as customizable, standard application software, which includes integrated business solutions for the core processes (Rosemann \& Wiese, 1999). 
considered as a major risk of ERP project implementation. The organization Fit is one of the principal factors leading to the implementation success. The resistance of change by the organization, partially because potential users resist the change; Kwahk and Lee (2008) highlight that the readiness of change was found to be enhanced by two principal factors: organizational commitment and perceived personal competence.

Before the evaluation of the ERP system, a framework has to be fixed and the characteristics of the system need to be taken into consideration. However, the context should dictate the appropriate specification and application of the ERP system (DeLone \& McLean, 2003, 1992). Although, many success variables are proposed by researchers to evaluate the ERP success and attempt to explain the causal and the process model adapted to propose their constructs and measurement variables. This question about the causal and process model has been discussed in the literature about the IS evaluation. The process model suggests that an IS is first created, containing various features, which can be characterized as exhibiting various degrees of system and information quality. In contrast, a causal model studies the covariance of the success dimensions to determinate if there exist a causal relationship among them (DeLone \& McLean, 2003).

To evaluate their information systems, organizations require appropriate methods and tools (Irani, 2002; Uwizeyemungu \& Raymond, 2010), they propose a new qualitative method for the ex-post evaluation of ERP system based on one hand on the organizational performance, and on the other hand on the automationed, informational and transformational effects that result from the integration and the use of the system. Their approach is based on a process model that takes into account at the same time practitioners' dimension of evaluation, and researchers' conception (Irani \& Love, 2008). This phenomenon of IS evaluation is complicated and multifaceted; it must be examined from many perspectives (Song \& Letch, 2012) and take into account different stakeholders involvement (Irani \& Love, 2008; Irani et al., 2014; Stefanou, 2001).

A CCP proposition could be considered as an important framework to assess the success of ERP system because this framework integrates three major dimensions of evaluation: content, context and process (Irani \& Love, 2008; Irani, 2002; Song \& Letch, 2012). This new approach of evaluation answers three main questions: Firstly, what is being measured (content) based on a socio-technological paradigm? Secondly, why and who of IS evaluation to be considered (context)? And thirdly how will it be undertaken? Many instruments could be used to answer this question like, cost benefits, ROI, ${ }^{2}$ user satisfaction that could be classified as a subjective evaluation approach.

According to the ERP evaluation success, a new framework of ex-ante evaluation was proposed by Stefanou (2001) to evaluate the ERP software. This framework includes in the same time behavioral, technological, and organizational perspective to evaluate the ERP software which is considered as a complex system (Irani, 2002; Stefanou, 2001). This step of success evaluation could be classified in the pre-implementation phase of the ERP integration process. It takes into account the selection process of the appropriate ERP software and all variables and criteria to select the most suitable one. The process of selection based on the one hand on both financial and nonfinancial approach and on the other hand it combines qualitative and quantitative measures (Stefanou, 2001). Relating to life-cycle product, the evolution of ERP integration process follows three phases: pre-implementation, implementation, and post-implementation. However, in this study we focus our classification of CSF's on two principal phases: First, the success factors according to implementation phase (Koh et al., 2011; Ngai et al., 2008). Secondly, success factors of ERP post-implementation project (Nicolaou \& Bhattacharya, 2006). We include both ex-ante and ex-post evaluation in to ERP success because it is considered as a process that involves CSF's throughout the ERP life-cycle.

This research paper will start with a presentation of the our theoretical model developed from the different frameworks, models and approaches discussed by searchers in the IS Evaluation success (Davis, 1989b; DeLone \& McLean, 2003, 1992; Gable et al., 2003; Ifinedo \& Nahar, 2006; Irani \& Love, 2008; Kaplan \& Norton, 1992; Rosemann \& Wiese, 1999; Seddon, 1997; Tsai et al., 2006); this theoretical model is based on three main theories: Firstly, the mathematical theory of communication (Weaver \& Shannon, 1949) used by Delone and McLean to develop their model about information success to explain the three levels that must be taken into account to evaluate IS success (technical level, semantic level, and effectiveness level). Secondly, the diffusion of innovations theory

\footnotetext{
${ }^{2}$ ROI: Return on investment
} 
(Rogers, 1983) mobilized by Bradford and Florin (2003) to explain the role of the diffusion of innovation on the ERP implementation success that will be used to involve and classify three principal factors in the conceptual model: technological; organizational, and environmental. Thirdly, the Adaptive Structuration Theory (DeSanctis \& Poole, 1994) was used to explain the interaction between the variables (factors) and the performance in three levels: individual, workgroup, and organizational performance.

We will expose our conceptual model and highlight the principal success factors identified in both theoretical models and empirical studies. After that, we will explain how these CSF's are classified taking into account the theoretical background in order to justify our conceptual perception. Then, we will explain the goal of our study and why a meta-analysis methodology was adopted. The methodology that we chose is a quantitative meta-analysis to identify the most significant factors that contribute to the ERP success in the different phases, depending on one side on Hunter et al.'s (1982) meta-analysis technique, and on the other side Lipsey and Wilson's (2004) practical meta-analysis. In this part, will we justify the use of this methodology and its contribution as the first study is interested in CSF's of the ERP system success. Later, we will examine the selection procedure of empirical studies and why our intention focuses only on studies published in the information system journals. Last, we will show both the process studies selection and treatment process of the effect size of every factor and its coefficient of correlation and its weight of success contribution.

Despite, meta-analysis is often criticized as a method mixing apples and oranges, but in this case we will choose only one choice to increase the reliability of the result. The meta-analysis method gives us a quantitative output, and it could compute the effect of variables and their contribution in the organizational performance. This study will give us the opportunity to design a new categorization of the CSF's and the value of each one in the ERP process based on the best published papers in the last decade.

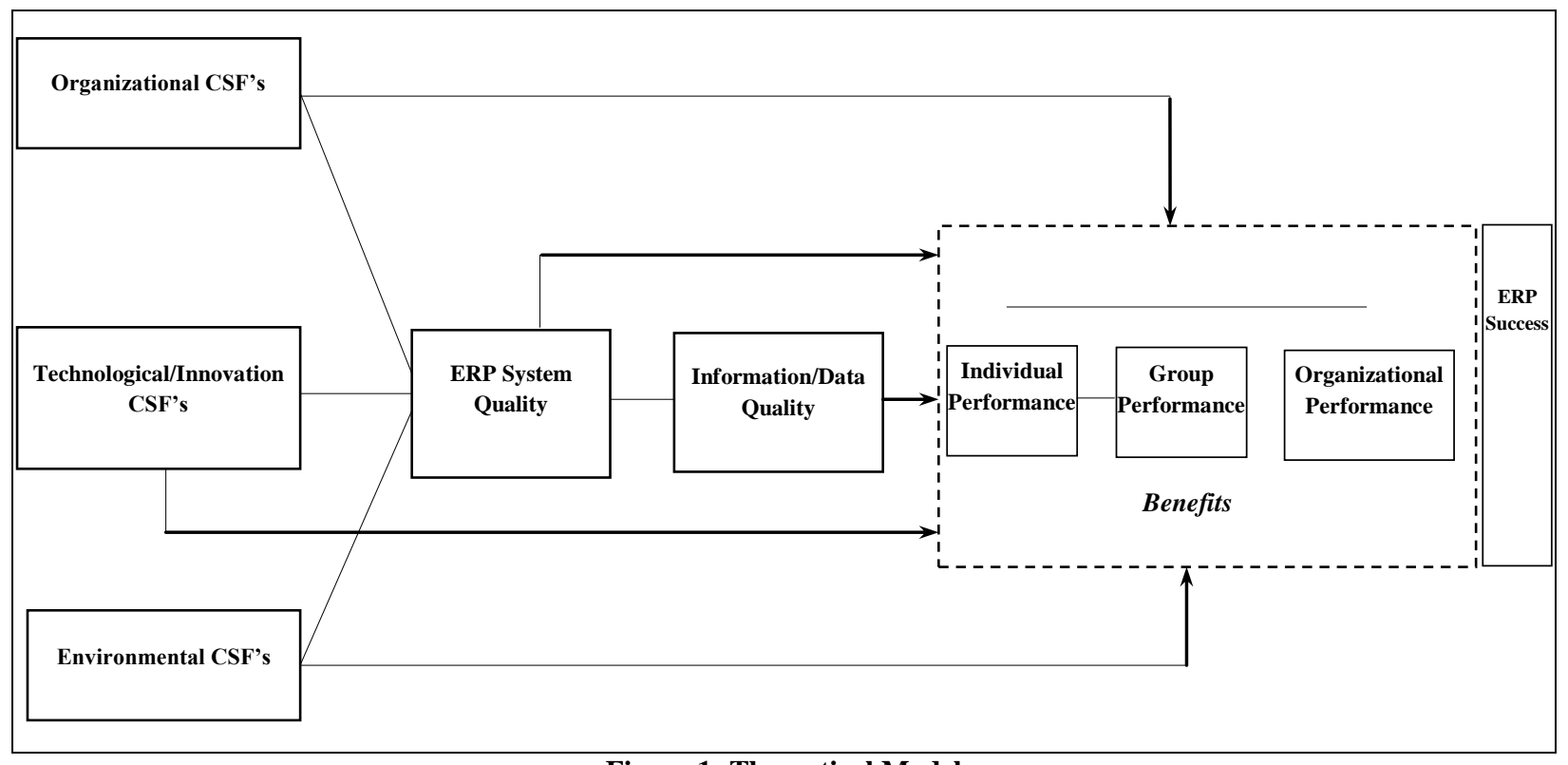

Figure 1: Theoretical Model

\section{CRITICAL SUCCESS FACTORS OF ERP SYSTEM}

Many critical factors were proposed to evaluate the success of the ERP system with different categories and taxonomies (Al-Mashari et al., 2003; Finney \& Corbett, 2007; Fui-hoon nah \& Delgado, 2006; Garcia-Sanchez \& Pérez-Bernal, 2007; Plant \& Willcocks, 2007; Somers \& Nelson, 2001; Zhang et al., 2002). This IS project success is defined by Lyytinen and Hirscheim (1987) as:

- $\quad$ Correspondence success, where there is a match between IT systems and specific planned objectives.

- $\quad$ Process success, when IT project is completed within time and budget. 
- Interaction success, when users' attitudes towards IT are positive.

- $\quad$ Expectation success, where IT systems match users' expectation.

The literature review about the success of the ERP system has shown an important number of CSF's. Some factors are present in the majority of the empirical studies but some others are not. Those present are considered as the most critical in the ERP system project success. Some researchers were interested in the following factors:

WGI: Myers et al. (1997) claimed that any system success model should include workgroup impact (WGI) and consider this factor as the contributions made by the teams/groups toward organizational productivity. The workgroup impact is an important stage between the individual and the organizational impacts, many organizations place a greater emphasis on the role of teams in the workplace (Ifinedo et al., 2010; Myers et al., 1997).

II: Individual impact is one of the most important factors determining the acceptance and the adoption of the technology by users. Thus, this factor is the most difficult to define in a non-ambiguous fashion (DeLone \& McLean, 1992). Many acceptance technology models are developed to investigate the question about the individual impact on the information system (Davis, 1989; Venkatesh \& Davis, 2000; Venkatesh et al., 2003). In the ERP system, this factor is determinant to perform the ERP project integration. Users' involvement, competence of users, training of users, users' resistance of change, user competency, and user knowledge of the system (Gorla \& Lin, 2010) are considered as individual factors in the ERP system success that must be taken into account by top management in the ERP system project.

OI: Organizational impact could be considered as a reciprocal impact between the organization and the technology. The first impact focuses on the organizational resistance, readiness of change, and organizational fit with the ERP system. The second impact could be explained by the contribution of the technology on the organizational performance improvement in operational tactical and strategic levels.

$S Q$ : System quality plays an important role in the information system success. This quality could be defined in terms of many attributes such as, data accuracy, database contents, ease of use, ease of learning, convenience of access, usefulness of use, realization of users' requirements, system accuracy, system flexibility, system reliability, system integration, system sophistication, system features and functions, integration of system, system efficiency, resources utilization, response time, and turnaround time (DeLone \& McLean, 1992). Software quality could be defined in terms of two main types of product characteristics: external quality such as, usability reliability, ease of use and usefulness, and internal quality, such as, software structure and complexity (Gorla \& Lin, 2010).

$I Q$ : The growth of data warehouse and the direct access of information by managers and information system users increase the need for, high quality information in organizations. To assess the quality of the information there are four main dimensions: Intrinsic IQ, Contextual IQ, Representational IQ, and Accessibility IQ (Lee et al., 2002). This information quality is considered by DeLone and McLean (1992) as a product of the information system that could be named IS output. They propose many criteria to measure the IQ such as, accuracy, output timeliness, reliability, completeness, relevance, precision, currency, accessibility, and adaptability.

TMS: Top Management Support is one of the most widely cited CSF's (Finney \& Corbett, 2007). This factor refers to the commitment of leadership to the diffusion of innovations (Somers \& Nelson, 2001) and is considered as the most critical factors in organizations embarking on ERP implementation (Al-Mashari et al., 2003). The decision to implement an ERP system is taken at the high level of organizational hierarchy, the senior management team input is crucial in the process of selecting of suitable vendor. The role of the leadership support and commitment does not end in this step of ERP system selecting, but must extend to the full implementation project (Al-Mashari et al., 2003). This factor is critical because management make fast and effective decisions, resolve conflicts, bring everyone to the same thinking to promote company-wide acceptance of the project, and build cooperation among the diverse groups in the organization (Sternad \& Bobek, 2012).

VCQ: The vendor/consultant service quality could be understood from many angles of attack such as: the vendor/consumer partnerships (Somers \& Nelson, 2001); the knowledge and capabilities of the consultant (Sternad 
\& Bobek, 2012); the communication and cooperation between the different stakeholders: client, consultant, and vendor (Finney \& Corbett, 2007); vendor transfers of knowledge, documents, services, and support. Both vendor and consultant quality were grouped together because they present an external source of expertise to the organization regarding ERP system implementation (Ifinedo \& Nahar, 2006). This factor could be considered as an external knowledge factor (Sedera \& Gable, 2010), that contributes to perform the ERP integration project throughout the product life cycle (implementation, upgrade, new version integration...). The VCQ factor can substitute the SQ (Service Quality) proposed by DeLone and McLean (2003) that must be added to the IS success model. The SERVQUAL concept is defined by Tsai et al. (2012) as the overall support delivered by the service supplier; they claimed that a poor user support can translate into lost costumers and lost sales. This concept is developed in the marketing to measure the service quality to evaluate the degree of users' satisfaction using five main dimensions (Tsai et al., 2012):

(1) Tangibles: Suppliers and consultants provide up-to-date hardware and software.

(2) Reliability: Suppliers and consultants are reliable.

(3) Responsiveness: Suppliers and consultants provide prompt service to users.

(4) Assurance: Suppliers and consultants have the knowledge to do their job better.

(5) Empathy: Suppliers and consultants have users' best interests at heart.

The main constructs used to measure the service quality in this study are:

- $\quad$ Vendor and consultant quality (Ehie \& Madsen, 2005; Ifinedo \& Nahar, 2006)

- $\quad$ Consulting services (Wang et al., 2008)

- $\quad$ External support (Zhu et al., 2010)

- $\quad$ Service quality (Chou \& Hong, 2013)

- $\quad$ Knowledge management competencies (Sedera \& Gable, 2010)

- $\quad$ External information acquisition for ERP adoption (Bernroider et al., 2014)

TED: A particular challenge in the ERP implementation is to select an appropriate plan for end-user training and education (Al-Mashari et al., 2003). Everyone who uses ERP systems needs to be trained on how they work and how they relate to the business process early on the implementation phase (Somers \& Nelson, 2001). Many ERP system adopters need the help of the consultants during the implementation project; this transfer of consultant's knowledge to internal employees is crucial to success and facilitates the ERP system adoption (Davenport, 1998). However, inadequate training and education could be considered as a significant reason for many ERP system failures (Al-Mashari et al., 2003; Bradford \& Florin, 2003; Umble et al., 2003).

$B P R$ : Business process reengineering, to benefit from all the advantages and best practices provided by the ERP system, business process redesign and change is required, because ERP systems are essentially developed to improve business processes such as manufacturing, purchasing, or distribution (Al-Mashari et al., 2003). To achieve the greatest benefits provided by the ERP system, it is imperative that the business processes are aligned with the new system (Somers \& Nelson, 2001). The new organizational business model after the business process reengineering is an enabling factor that contributes to the ERP success. The main appellations used to indicate the BPR:

- $\quad$ Business process reengineering (Bradford \& Florin, 2003; Ehie \& Madsen, 2005; Ram et al., 2013a)

- $\quad$ Business process improvement (Bernroider, 2008; Bernroider et al., 2014; Law \& Ngai, 2007)

- $\quad$ Business process adaptation (Hong \& Kim, 2002)

- $\quad$ Business process change (Velcu, 2010)

$P M$ : Project Management concerns all the human, technological, and financial resources used to perform the ERP system project respecting budget and schedule estimations. To manage successfully the ERP integration, project managers must be capable both in strategic and tactical project management activities (Al-Mashari et al., 2003). This factor refers to the ongoing management of the implementation plan. It involves not only the planning stages, but also the allocating of responsibilities to various players (Finney \& Corbett, 2007). The project 
management needs to establish a steering committee comprised of senior management, senior project management, and ERP end users that should be involved in all the ERP integration phases (Finney \& Corbett, 2007; Somers \& Nelson, 2001).

$E R P / F$ : ERP Fit, this factor includes many constructs such as system integration (Al-Mashari et al., 2003; Grant et al., 2013; Ram et al., 2013b), system configuration (Zhu et al., 2010), customization (Somers \& Nelson, 2001; Sternad \& Bobek, 2012), technical compatibility (Bradford \& Florin, 2003), and ERP Fit and alignment (Bernroider et al., 2014; Wang \& Chen, 2006). The ERP system integration requires some modifications that should take into consideration both ERP system features and organization specificities; this fit between the organization and the ERP system is a critical factor of success. The integrative design of the ERP systems increases the complexity involved in source code modification (Sternad \& Bobek, 2012). Organizations seek competitive advantage by aligning with other organizations, usually for their non-core business activities, and thus may intend to integrate ERP with partner systems (Ram et al., 2013a). System integration/configuration is considered as a CSF's at the deployment stage of ERP (Al-Mashari et al., 2003). This result reinforces the importance of ensuring that all the ERP modules are interfaced for the seamless operation of ERP system and allow successful implementation (Ram et al., 2013a).

In the following table we expose all the critical success factors identified in 32 articles selected for our mete-analysis. In the columns we find the eleven CSF's most cited by the researchers in the last ten years and in the lines, researchers who have studied quantitatively these factors. We can see that in one study many factors may be treated.

Table 1: Critical Success Factors

\begin{tabular}{|c|c|c|c|c|c|c|c|c|c|c|c|}
\hline Authors & 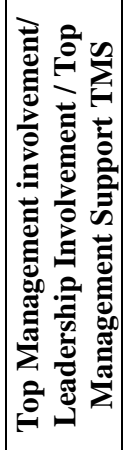 & 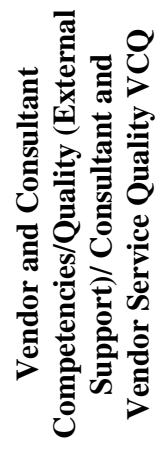 & 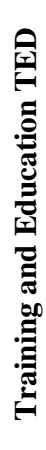 & 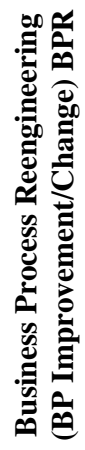 & 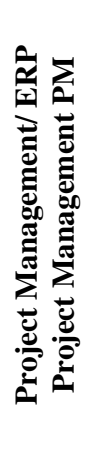 & 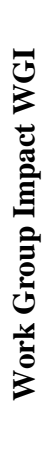 & 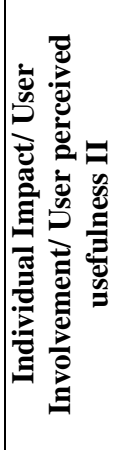 & 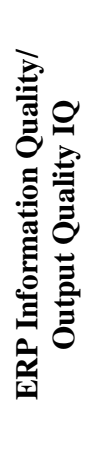 & 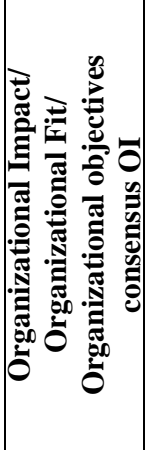 & 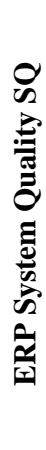 & 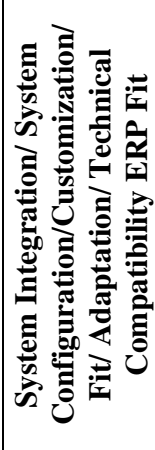 \\
\hline (Gable et al., 2003) & & & & & & & $\checkmark$ & $\checkmark$ & $\checkmark$ & $\checkmark$ & \\
\hline (Ifinedo \& Nahar, 2006) & & $\checkmark$ & & & & $\checkmark$ & $\checkmark$ & $\checkmark$ & $\checkmark$ & $\checkmark$ & \\
\hline (Ram et al., 2013a) (a) & & & $\checkmark$ & $\checkmark$ & $\checkmark$ & & & & & & $\checkmark$ \\
\hline (Ifinedo et al., 2010) & & $\checkmark$ & & & & $\checkmark$ & $\checkmark$ & $\checkmark$ & $\checkmark$ & $\checkmark$ & \\
\hline (Law \& Ngai, 2007) & & & & $\checkmark$ & & & & & & & \\
\hline (Candra, 2012) & & & & & & & $\checkmark$ & $\checkmark$ & $\checkmark$ & $\checkmark$ & \\
\hline (Zhu et al., 2010) & $\checkmark$ & $\checkmark$ & & & $\checkmark$ & & & & $\checkmark$ & & $\checkmark$ \\
\hline (Hong \& Kim, 2002) & & & & $\checkmark$ & & & & & $\checkmark$ & & \\
\hline (Velcu, 2010) & & & & $\checkmark$ & $\checkmark$ & & & & & & \\
\hline (Ehie \& Madsen, 2005) & $\checkmark$ & $\checkmark$ & & $\checkmark$ & $\checkmark$ & & & & & & \\
\hline (Bernroider, 2008) & & & & $\checkmark$ & & & & $\checkmark$ & & & \\
\hline (Sedera \& Gable, 2010) & & $\checkmark$ & & & & & $\checkmark$ & & $\checkmark$ & $\checkmark$ & \\
\hline (Bradford \& Florin, 2003) & $\checkmark$ & & $\checkmark$ & $\checkmark$ & & & & & $\checkmark$ & & $\checkmark$ \\
\hline (Chou \& Hong, 2013) & & $\checkmark$ & & & & & $\checkmark$ & $\checkmark$ & & $\checkmark$ & \\
\hline (Ifinedo, 2011) & & & & & & & $\checkmark$ & $\checkmark$ & & $\checkmark$ & \\
\hline (Ram et al., 2013b) (b) & & & $\checkmark$ & $\checkmark$ & $\checkmark$ & & & & & & $\checkmark$ \\
\hline (Wang et al., 2008) & $\checkmark$ & $\checkmark$ & & & $\checkmark$ & & & $\checkmark$ & & & \\
\hline (Yoon, 2009) & & & & & & & & $\checkmark$ & & & \\
\hline (Choi et al., 2007) & & & $\checkmark$ & & & & & & & $\checkmark$ & \\
\hline (Scott \& Walczak, 2009) & $\checkmark$ & $\checkmark$ & & & & & & & & & \\
\hline
\end{tabular}


Table 1 cont.

\begin{tabular}{|c|c|c|c|c|c|c|c|c|c|c|}
\hline (Amoako-Gyampah, 2007) & & & & & & & & & $\checkmark$ & \\
\hline (Wang \& Chen, 2006) & & & & & & & & & & $\checkmark$ \\
\hline (Chien et al., 2007) & & & & & $\checkmark$ & & & & & \\
\hline (Tsai et al., 2012) & & $\checkmark$ & & & & $\checkmark$ & & & $\checkmark$ & \\
\hline (Kwahk \& Lee, 2008) & $\checkmark$ & & & & & & & & $\checkmark$ & \\
\hline (Chou \& Chang, 2008) & & & & & & & & $\checkmark$ & & \\
\hline (Grant et al., 2013) & & & & & & & & $\checkmark$ & & $\checkmark$ \\
\hline (Sun et al., 2009) & & & & & & & & & $\checkmark$ & \\
\hline (Bernroider et al., 2014) & $\checkmark$ & $\checkmark$ & $\checkmark$ & $\checkmark$ & & & & & & $\checkmark$ \\
\hline (Lapiedra et al., 2011) & & $\checkmark$ & & & & & & & & \\
\hline (Chung et al., 2008) & $\checkmark$ & $\checkmark$ & & & & & $\checkmark$ & & $\checkmark$ & \\
\hline (Shih \& Huang, 2009) & $\checkmark$ & & & & & & & & $\checkmark$ & $\checkmark$ \\
\hline
\end{tabular}

\section{RESEARCH METHODOLOGY}

The literature review related to the success of ERP system provides an important number of empirical studies. Throughout the past two decades, researchers have investigated the question about the determinants of the ERP system success in order to understand better their impacts both on organizational and individual performance. The divergent results of studies about the CSF's lead us to investigate the quantitative review to determine the effect size magnitude (Lipsey \& Wilson, 2004) of each factor in the success process of the ERP System and its benefit in both practice and research. The most appropriate methodology to answer this question is not to add a new study with a new result but to combine all the extant studies in a meta-analysis cumulating all research findings (Hunter et al., 1982). The choice of this methodology is motivated by both the nature of the extant results studies and the feasibility of quantifying the findings results in one study.

Meta-analysis is one of many ways to summarize, integrate, and interpret selected sets of scholarly works in various fields (Lipsey \& Wilson, 2004) like, psychology, medicine, and recently in management (Chau, 1999; King \& He, 2006; Petter \& McLean, 2009; Wu et al., 2011, Laroche \& Soulez, 2012; Wu \& Lederer, 2009). The studies that we can use in meta-analysis are those using a quantitative measurement of variables and reporting descriptive or inferential statistics that summarize the resulting data. The meta-analysis is a technique for encoding and analyzing the statistics that summarize research findings as they are typically presented in research reports (Lipsey \& Wilson, 2004). The meta-analysis should use an effect size statistic that provides appropriate standardization for the particular research form design of quantitative finding, variables, and operationalization presented in the set of studies under investigations (Lipsey \& Wilson, 2004).

The process of meta-analysis is defined by Glass as a composite process: Starting by cumulating descriptive statistics across the studies, coding study characteristics, and finally the regression of study outcome onto the coded study characteristics (Hunter et al., 1982, p. 32). In the course of doing meta-analysis, the steps would be: (1) search for and gather studies, (2) extract information from the studies, and (3) cumulate the information extracted; these are the main three steps of the meta-analysis process as defined by Hunter et al. (1982).

\section{Strengths of Meta-Analysis}

Using a meta-analysis to summarize and analyze results of research studies is more reliable than conventional research reviewing techniques (Lipsey \& Wilson, 2004); there are four main reasons that constitute the advantages of meta-analysis: Firstly, meta-analysis methodology imposes a useful discipline on the process of cumulating research results; secondly, the meta-analysis summarizes key study results in a way that they are more differentiated and sophisticated than the traditional review procedures; thirdly, meta-analysis is able to find effects or relationships that are obscured in other approaches to summarize research; fourthly, meta-analysis provides an organized manner of handling information from a huge number of study findings under review.

\section{Identifying and Selecting Studies}

The meta-analysis process starts by identifying studies. To identify these studies, we use both online databases accessible via our university and Google scholar as a supplementary tool for optionally adding other 
studies that go unnoticed. Online databases used in our research are: Science Direct, JSTOR, Taylor \& Francis, Wiley, and Springer link, but the majority of articles were found in Science Direct. The main subject of this step of meta-analysis process is to include as many published studies as possible to enhance the reliability of our result. In the process of identifying studies we fixed many criteria of research such as: keywords used in the article title and abstract, including only the studies published between 2002 and 2014, using the following keywords: ERP system success, CSF's, ERP system, performance, effectiveness, ERP benefits. These keywords are used in the advanced research option in the online databases using all the combinations possible. We also sought the studies that referred to IS Success model such as the DeLone \& McLean model, TAM Model. We examined the references of each article for probably finding new studies.

After the first step of identifying studies using all possibilities to enhance the number of articles published in the period between 2002 and 2014, we selected only the articles that used a quantitative approach. Our metaanalysis includes studies according to two criteria: Firstly, the studies that reported the correlation coefficient; secondly we retained only the articles that treated the success of ERP System taking on consideration three levels of performance: individual, work group, and organizational performance. Taking into account these three levels of performance as a measurement criterion of the ERP System success that have been justified both theoretically and empirically by an important number of researchers. In the individual level, all studies that used TAM model assess the ERP Success in the individual impact using the following items: User satisfaction, individual performance, computer self-efficacy and user satisfaction, ERP efficacy usage and perceived usefulness. Studies based on DeLone $\&$ McLean Model use two levels of performance measurement, individual and organizational; some studies used the three level indicated above. Focusing on only one level of performance measurement was not possible for many reasons, the theoretical measurement model interested in ERP success take into account all the three levels (Gable et al., 2003; Ifinedo \& Nahar, 2006; Ifinedo, 2011; Ifinedo et al., 2010; Sedera \& Gable, 2010), thus the feature of ERP system must take into account the success evaluation process. The characteristic of the IS must be taken into consideration in the evaluation process (DeLone \& McLean, 1992; Gable et al., 2003; Seddon, 1997).

We followed the process used in other meta-analysis in information system to develop our final database and for encoding studies selected to be summarized in our meta-analysis (e.g., Chau, 1999; King \& He, 2006; Petter \& McLean, 2009; Wu et al., 2011), hence we followed a procedure in a meta-analysis used in marketing which developed a conceptual model from the extant results (Kirca et al., 2005). 


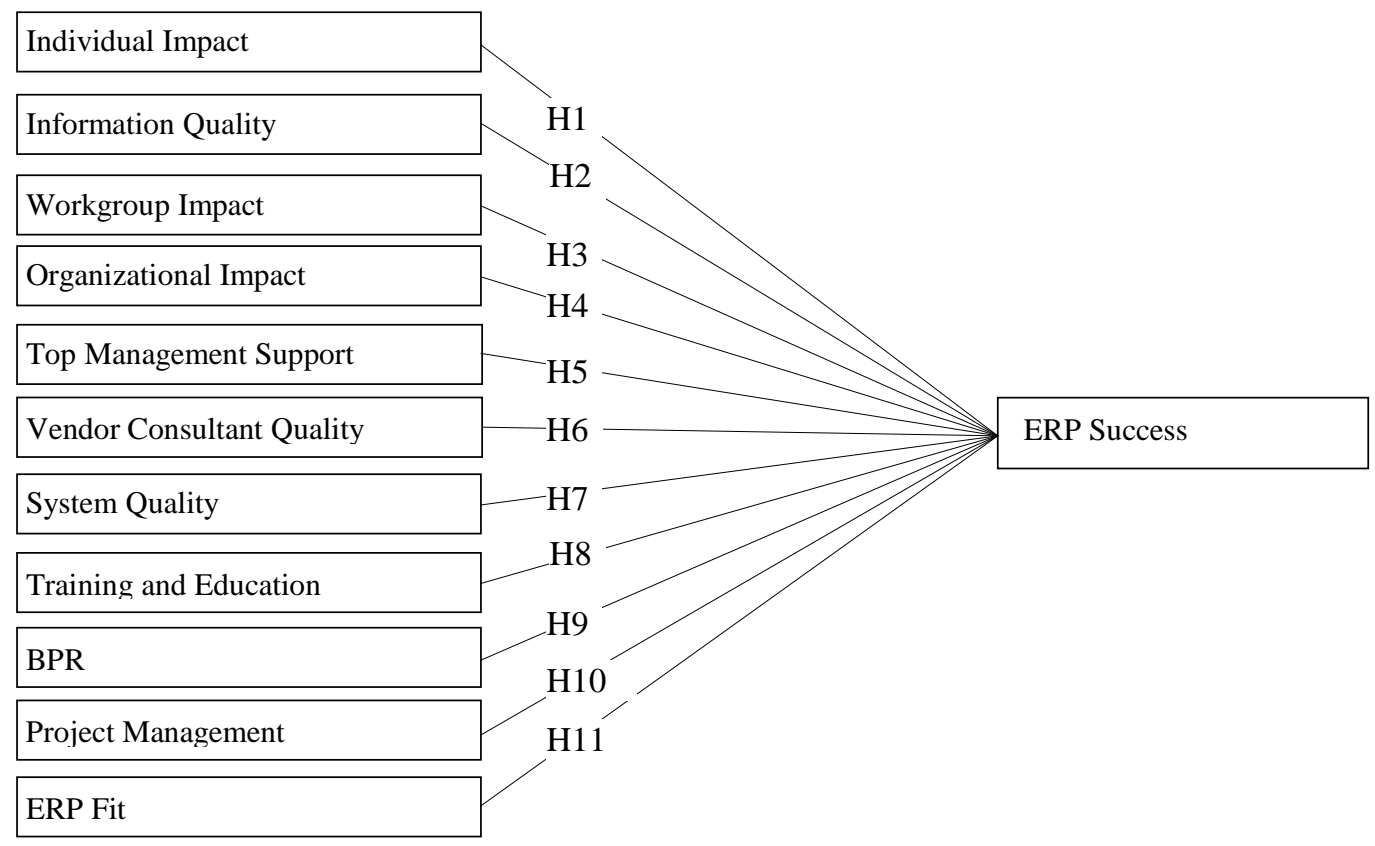

Figure 2: Hypothesized Model

The result of our first research before selecting studies:

Table 2: Publications by Journal

\begin{tabular}{|l|c|}
\hline \multicolumn{1}{|c|}{ Journal Title } & Publications \\
\hline Information \& Management & 10 \\
\hline International Journal of Production Economics & 8 \\
\hline International Journal of Information System & 7 \\
\hline Computers in Industry & 6 \\
\hline Procedia Technology & 6 \\
\hline Computers in Human Behavior & 5 \\
\hline European Journal of Operational Research & 5 \\
\hline International Journal of Accounting Information... & 4 \\
\hline The Journal of Strategic Information Systems & 3 \\
\hline International Journal of Project Management & 2 \\
\hline Information Systems & 2 \\
\hline Decision Support Systems & 2 \\
\hline Journal of Systems and Software & 1 \\
\hline Advanced Engineering Informatics & 1 \\
\hline Computer Standards \& Interfaces & 1 \\
\hline Human Resource Management Review & 1 \\
\hline International Journal of Human-Computer Studies & 1 \\
\hline The Journal of High Technology Management Research ... & 1 \\
\hline Practical E-Manufacturing and Supply Chain Management & 1 \\
\hline Journal of Information Technology Management & 1 \\
\hline Social and Behavioral Sciences & 1 \\
\hline International Journal of Information Management & 1 \\
\hline Computers in Industry & 1 \\
\hline Journal of Manufacturing Systems & 1 \\
\hline The Service Industries Journal & 1 \\
\hline Journal of Computing in Civil Engineering & 1 \\
\hline Journal of Research and Practice in Information Technology & 1 \\
\hline International Conference on Information Systems” & 1 \\
\hline & \\
\hline
\end{tabular}


Table 3: The 32 Studies Selected for our Meta-Analysis

\begin{tabular}{|l|c|}
\hline Information Management & 8 \\
\hline Computers in Human Behavior & 4 \\
\hline The Journal of Systems and Software & 2 \\
\hline International Journal of Production Economics & 2 \\
\hline International Journal of Project Management & 2 \\
\hline Decision Support Systems & 2 \\
\hline "International Conference on Information Systems" & 1 \\
\hline Journal of Information Technology Management & 1 \\
\hline Social and Behavioral Sciences & 1 \\
\hline International Journal of Information Management & 1 \\
\hline Computers in Industry & 1 \\
\hline The Journal of Strategic Information System & 1 \\
\hline International Journal of Accounting Information Systems & 1 \\
\hline Journal of Manufacturing Systems & 1 \\
\hline International Journal of Human Computer Studies & 1 \\
\hline The Service Industries Journal & 1 \\
\hline Journal of Computing in Civil Engineering & 1 \\
\hline Journal of Research and Practice in Information Technology & 1 \\
\hline Total & 32 \\
\hline
\end{tabular}

Tables $(1,2,3)$ presented above summarize the articles used in the meta-analysis and classify them using three main criteria: topic, year of publication, and journal. Table 2 shows all the articles found in the first step of collecting studies and presents the result of our research using the following key words: ERP system, ERP system success, ERP system performance, and ERP CSF's. Table 3 presents only the articles including a quantitative methodology (correlation coefficient) needed to compute the effect size.

\section{Coding Studies}

This step is focused on the extraction of the information from each study selected. To accomplish this task we use an excel table with the coded study criteria (Hunter et al., 1982) such as the date, journal, authors, and sample size. We included as many criteria as possible in our database to lead our meta-analysis. We also carefully selected the measurement items of each construct. This step was critical because the constructs are not always measured by the same items, for example IQand SQ could be measured using different items; for this reason we used Cronbach's alpha or inter-item reliability scores for each construct (Chau, 1999; Petter \& McLean, 2009).

Cronbach's alpha $\alpha=\frac{k}{k-1}\left[1-\frac{\sum \sigma_{i}^{2}}{\sigma_{x}^{2}}\right]$

$\mathrm{K}$ indicates the number of items; $\sum \sigma_{i}^{2}$ is the sum of the variances of the items, and $\sigma_{x}^{2}$ is the variance of total score. In our case Cronbach's alpha is indicated in each study used in our meta-analysis.

When coding our finding results, we classified them into different categories, for example the geographic context: America, Asia, Europe, and Australia. The respondents function: ERP Users, ERP project Manager, Senior ERP Manager, CIO's, and some studies focus on various hierarchical levels of respondents. Two studies used in our research have taken into account students as respondents to assess the ERP success system; these two studies measure the individual performance level using the technology acceptance model (Davis, 1989b). Therefore, we classified the selected studies into two principal categories: public and private sector, and the two studies mentioned above are classified in the education sector because they were applied on students in two different universities.

Then 32 studies with 124 effect sizes have been encoded according to the criteria that have been fixed after the step of identifying and selecting study. Our initial research produced more than 80 papers, 48 of them were eliminated because they were not empirical studies with an effect size. We saved only the empirical studies that have provided a correlation coefficient, sample size, p-value, and reliability of constructs (using Cronbach's alpha). 


\section{Data Analysis}

In the meta-analysis there are two main families of effects size: the $\boldsymbol{r}$ family and the $\boldsymbol{d}$ family; the two most important members of the former are Persons' product-moment correlations $(\boldsymbol{r})$ and $(\boldsymbol{Z} \boldsymbol{r})$, Fisher's $\boldsymbol{r}$ to- $\boldsymbol{z}$ transformation. The three most important members of the d family are Cohen's $\boldsymbol{d}$, Hedge's $\boldsymbol{g}$, and Glass's $\Delta$ (Rosenthal, 1995). To analyze our data, we had the possibility to follow one of the three meta-analysis techniques (Hedges-Olkin, Rosenthal-Rubin, and Hunter-Schmidt methods).

Recently many sophisticated meta-analysis software were developed to help researchers in their data analysis, like (Revman, CMA etc). The advantages of using meta-analysis software are: The possibility to create and customize graphics for interpretation and the facility for data entry.

However, in our meta-analysis we will use both conventional technique using Excel as a support for computing the effect size, and CMA software (Comprehensive Meta-Analysis software) to analyze our data and to confirm results that were found before. Based on articles published in IS (e.g., Petter \& McLean, 2009) using a meta-analysis, the most appropriate technique selected to analyze our data was the Hunter and Schmidt technique. After gathering the correlation coefficient from each study, this technique appears to be the most appropriate because it is based on the correlation coefficient to compute the effect size.

\section{Cumulating Correlations Across Studies (Hunter \& Schmidt Technique)}

This technique considers the correlation coefficient as a subject to two principal sources of error that can be eliminated at the level of meta-analysis: sampling error and error of measurement. In our meta-analysis we will eliminate both the sampling error and the error of measurement for each construct based on the criterion reliability (as reported using Cronbach's alpha).

\section{Eliminating the Sampling Error}

Hunter \& Schmidt report that if the population correlation is assumed to be constant over studies, the best estimate of that correlation is not the sample mean across studies but a weighted average in which each correlation is weighted by the number of persons in that study. The formula to estimate the population correlation is:

$\bar{r}=\frac{\sum\left[N_{i} r_{i}\right]}{\sum N_{i}}$

where $r_{i}$ is the correlation in study I and $N_{i}$ is the number of people in study $i$. The corresponding variance across studies is the frequency weighted average squared error:

$s_{r}^{2}=\sigma_{r}^{2}=\frac{\sum\left[N_{i}\left(r_{i}-\bar{r}\right)^{2}\right]}{\sum N_{i}}$

To compute the error variable $e_{i}$ (sampling error in the sample correlation in study i.) we use the following formula:

$r_{i}=\rho_{i}+e_{i}$

and its variance:

$\sigma_{e_{i}}^{2}=\frac{\left(1-\rho_{i}^{2}\right)^{2}}{N_{i}-1}$

The error variance across studies is computed using the following formula:

$\sigma_{e}^{2}=\frac{\left(1-\bar{r}^{2}\right)^{2} K}{N}$ 
where $\mathrm{K}$ is the number of studies and $N=\sum N_{I}$ is the total sample size. And the error variance of the population correlation is computed with following formula:

$\sigma_{\rho}^{2}=\sigma_{r}^{2}-\sigma_{e}^{2}$

After computing the variance, we then calculated $95 \%$ confidence interval of the correlation corrected only for the sampling error using the standard deviation (computing from the variance). Confidence intervals that don't include zero consider that the relationship is significant.

Confidence interval: $\bar{r}+/-1.96 \sigma_{e}$

\section{Eliminating the Measurement Error}

Variables in management science are not perfectly measured (Hunter et al., 1982). There is always an effect of error of measurement on the correlation between variables, the error of measurement automatically lowers the correlation coefficient, and this effect must be eliminated in the meta-analysis. To eliminate this effect the true measurement scores of both dependent and independent variables must be computed:

$\rho=\frac{r_{\text {corrected }}}{\sqrt{\text { reliability }} \sqrt{\text { reliability }}}=\frac{\bar{r}_{x y}}{\sqrt{r_{x x}} \sqrt{r_{y y}}}$

where, $\overline{\mathrm{r}}$ is the correlation corrected for the sampling error, $\sqrt{\mathrm{r}_{\mathrm{xx}}}$ is the reliability of the independent variable and $\sqrt{r_{\mathrm{yy}}}$ is the reliability of the dependent variable.

Based on Petter and McLean's (2009) meta-analysis, another test must be computed; this test is a homogeneity test which determines if there is heterogeneity in the correlations in a meta-analysis, this heterogeneity, often suggests that an additional variable is creating the variance and affecting the effect size. To know if the studies are homogeneous, credibility interval must be determined using the corrected standard deviation using the following formula:

$\sigma_{e_{\rho}}^{2}=\frac{\sigma_{e}^{2}}{r_{x x} r_{y y}}$

Lower Endpoint $=\frac{\bar{r}-1,96 \sigma_{e}}{\sqrt{r_{x x}} \sqrt{r_{y y}}}$ and Upper Endpoint $=\frac{\bar{r}+1,96 \sigma_{e}}{\sqrt{r_{x x}} \sqrt{r_{y y}}}$

Each study contains all the information to correct correlation for attenuation due to both sampling error and measurement error. At first we corrected the correlation for the sampling error, and then we computed the 95\% confidence interval of the corrected correlation from the sampling error. Secondly we based ourselves on the reliability of both independent and dependent variable to compute the average of each one over studies using Cronbach's alpha as reported. After that, we compute the correlation corrected for measurement error $(\rho)$ and its credibility interval using the formula mentioned above (11).

\section{Meta-Analysis Result}

The study presented in this work summarizes quantitatively the relationship between the CSF's and the ERP system success. After identifying the CSF's selected from empirically studies we classified them into three main taxonomy of significant magnitude, strong, moderate and weak. 
Table 4: Meta-Analysis Results

\begin{tabular}{|c|c|c|c|c|c|c|}
\hline Significant Magnitude & Meta-Analysis & CSF & $\mathbf{N}$ & $\mathbf{K}$ & $\rho$ & $\mathbf{F z}$ \\
\hline \multirow[t]{4}{*}{ Strong } & $\mathrm{H} 1$ & II & 1559 & 10 & 0,845 & 0.932 \\
\hline & $\mathrm{H} 2$ & IQ & 1940 & 13 & 0,775 & 0.846 \\
\hline & H3 & WGI & 389 & 4 & 0,766 & 0.813 \\
\hline & $\mathrm{H} 7$ & SQ & 3545 & 19 & 0.724 & 0.780 \\
\hline \multirow[t]{5}{*}{ Moderate } & $\mathrm{H} 4$ & $\mathrm{OI}$ & 1611 & 13 & 0,635 & 0.760 \\
\hline & $\mathrm{H} 5$ & TMS & 1455 & 10 & 0,578 & 0.595 \\
\hline & H6 & VCQ & 2007 & 14 & 0,494 & 0.517 \\
\hline & $\mathrm{H} 8$ & TED & 960 & 6 & 0,460 & 0.435 \\
\hline & H9 & BPR & 1560 & 13 & 0,353 & 0.374 \\
\hline \multirow[t]{2}{*}{ Weak } & $\mathrm{H} 10$ & PM & 932 & 8 & 0,324 & 0.310 \\
\hline & H11 & ERP/F & 1594 & 11 & 0,305 & 0.304 \\
\hline
\end{tabular}

Statistically significant at: $\rho<0.0001$

One of the benefits of the meta-analysis methodology is its ability to classify the strength of the relationships between the constructs (Lipsey \& Wilson, 2004; Petter \& McLean, 2009). The result of this study shows that the most significant factors in the ERP process success are: the individual impact in the first position $(\rho=0,845 ; \mathrm{Fz}=0.932)$, the information quality $(\rho=0.775 ; \mathrm{Fz}=0.846)$; the workgroup impact $(\rho=0.766 ; \mathrm{Fz}=$ $0.813)$, and the ERP system quality $(\rho=0.724 ; \mathrm{Fz}=0.780)$. All these factors are an important impact on the ERP success. However, the organizational impact, top management support, vendor and consultant quality, training and education and the business process factors have a moderate magnitude with successively $(\rho=0.635 ; \mathrm{Fz}=0.760)$ $(\rho=0.578 ; \mathrm{Fz}=0.595)(\rho=0.494, \mathrm{Fz}=0.517) ;(\rho=0.460, \mathrm{Fz}=0.435) ;(\rho=0.353, \mathrm{Fz}=0.374)$. And, finally in the last position, project management and ERP/Fit factors with a weak magnitude $(\rho=0.324, \mathrm{Fz}=0.310$; $\rho=0.305, \mathrm{Fz}=0.304)$. We found that there is a significant relationship between CSF's and the success of the ERP system; most of these relationships are strong or moderate. 
Table 5: Excel Meta-Analysis Results

\begin{tabular}{|c|c|c|c|c|c|c|c|c|c|c|c|c|c|c|c|c|c|c|}
\hline Hypothesis & $\mathbf{K}$ & $\sum N_{i}$ & $\sum\left[\boldsymbol{N}_{i} \boldsymbol{r}_{i}\right]$ & $\overline{\boldsymbol{r}}$ & $\sum_{\left.-\overline{\boldsymbol{r}})^{2}\right]}\left[\boldsymbol{N}_{\boldsymbol{i}}\left(\boldsymbol{r}_{\boldsymbol{i}}\right.\right.$ & $\sigma_{r}^{2}$ & $\sigma_{r}$ & $\sigma_{e}^{2}$ & $\sigma_{e}$ & $\begin{array}{c}95 \% \\
\text { Confidence } \\
\text { interval }\end{array}$ & $\sigma_{\rho}^{2}$ & $\sigma_{\rho}$ & $r_{x x}$ & $r_{y y}$ & $\rho$ & $\sigma_{e_{\rho}}^{2}$ & $\sigma_{e_{\rho}}$ & $\begin{array}{c}\mathbf{9 5 \%} \\
\text { Credibility } \\
\text { Interval }\end{array}$ \\
\hline $\begin{array}{l}\text { H1: There is a } \\
\text { positive and } \\
\text { significant } \\
\text { relationship between } \\
\text { the Individual } \\
\text { Impact and the ERP } \\
\text { success }\end{array}$ & 10 & 1559 & 1129,049 & 0,724 & 8,204 & 0,005 & 0,073 & 0,001 & $\mathbf{0 , 0 3 8}$ & $0,65-0,79$ & 0,004 & 0,062 & 0,808 & 0,908 & $\mathbf{0 , 8 4 5}$ & 0,002 & 0,044 & $0,76-0,93$ \\
\hline $\begin{array}{l}\text { H2: There is a } \\
\text { positive and } \\
\text { significant } \\
\text { relationship between } \\
\text { the Information/ } \\
\text { Data Quality and the } \\
\text { ERP success }\end{array}$ & 13 & 1940 & 1307,849 & 0,674 & 20,792 & 0,011 & 0,104 & 0,002 & 0,045 & $0,58-0,76$ & 0,009 & 0,093 & 0,832 & 0,908 & 0,775 & 0,003 & 0,051 & $0,67-0,87$ \\
\hline $\begin{array}{l}\text { H3: There is a } \\
\text { positive and } \\
\text { significant } \\
\text { relationship between } \\
\text { the Work Group } \\
\text { Impact and the ERP } \\
\text { success }\end{array}$ & 4 & 389 & 260,691 & 0,670 & 0,253 & 0,001 & 0,026 & 0,003 & 0,056 & $0,56-0,78$ & 0,002 & 0,050 & 0,843 & 0,908 & 0,766 & 0,004 & 0,064 & $0,64-0,89$ \\
\hline $\begin{array}{l}\text { H4: There is a } \\
\text { positive and } \\
\text { significant } \\
\text { relationship between } \\
\text { the Organizational } \\
\text { impact and the ERP } \\
\text { success }\end{array}$ & 13 & 1611 & 888,202 & 0,551 & 224,064 & 0,139 & 0,373 & 0,004 & 0,063 & $0,43-0,67$ & 0,135 & 0,368 & 0,829 & 0,908 & 0,635 & 0,005 & 0,072 & $0,49-0,77$ \\
\hline $\begin{array}{l}\text { H5: There is a } \\
\text { positive and } \\
\text { significant } \\
\text { relationship between } \\
\text { the Top } \\
\text { Management } \\
\text { Support and the ERP } \\
\text { success }\end{array}$ & 10 & 1455 & 747,688 & 0,514 & 30,887 & 0,021 & 0,146 & 0,004 & 0,061 & $0,39-0,63$ & 0,018 & 0,132 & 0,870 & 0,908 & 0,578 & 0,005 & 0,069 & $0,44-0,71$ \\
\hline $\begin{array}{l}\text { H6: There is a } \\
\text { positive and } \\
\text { significant } \\
\text { relationship between } \\
\text { the Vendor and } \\
\text { Consulting Quality } \\
\text { and the ERP success }\end{array}$ & 14 & 2007 & 870,371 & $0, \mathbf{4 3 4}$ & 153,244 & 0,076 & 0,276 & 0,005 & 0,068 & $0,30-0,56$ & 0,072 & 0,268 & 0,848 & 0,908 & 0,494 & 0,006 & $\mathbf{0 , 0 7 7}$ & $0,34-0,64$ \\
\hline
\end{tabular}




\begin{tabular}{|c|c|c|c|c|c|c|c|c|c|c|c|c|c|c|c|c|c|c|}
\hline $\begin{array}{l}\text { H7: There is a } \\
\text { positive and } \\
\text { significant } \\
\text { relationship between } \\
\text { the System Quality } \\
\text { and the ERP success }\end{array}$ & 19 & 3545 & 1512,631 & 0,635 & 50,434 & 0,014 & 0,119 & 0,002 & 0,044 & $0,55-0,72$ & 0,012 & 0,111 & 0,847 & 0,908 & 0,724 & 0,002 & 0,050 & $0,62-0,82$ \\
\hline $\begin{array}{l}\text { H8: There is a } \\
\text { positive and } \\
\text { significant } \\
\text { relationship between } \\
\text { the Training and } \\
\text { Education and the } \\
\text { ERP success }\end{array}$ & 6 & 960 & 386,262 & 0,402 & 13,996 & 0,015 & 0,121 & 0,004 & 0,066 & $\mathbf{0 , 2 7}-\mathbf{0 , 5 3}$ & $\mathbf{0 , 0 1 0}$ & 0,101 & 0,842 & 0,908 & 0,460 & $\mathbf{0 , 0 0 6}$ & 0,076 & $0,31-0,61$ \\
\hline $\begin{array}{l}\text { H9: There is a } \\
\text { positive and } \\
\text { significant } \\
\text { relationship between } \\
\text { the Business Process } \\
\text { Reengineering and } \\
\text { the ERP success }\end{array}$ & 13 & 1560 & 483,598 & 0,310 & 191,718 & 0,123 & 0,351 & 0,007 & 0,083 & $0,14-0,47$ & 0,116 & 0,341 & 0,848 & 0,908 & $\mathbf{0 , 3 5 3}$ & 0,009 & 0,094 & $0,17-0,53$ \\
\hline $\begin{array}{l}\text { H10: There is a } \\
\text { positive and } \\
\text { significant } \\
\text { relationship between } \\
\text { the Project } \\
\text { Management and the } \\
\text { ERP success }\end{array}$ & 8 & 932 & 275,668 & 0,296 & 11,159 & 0,012 & 0,109 & 0,007 & 0,085 & 0,13 - 0,46 & 0,005 & 0,069 & 0,915 & 0,908 & 0,324 & 0,009 & 0,093 & $0,14-0,50$ \\
\hline $\begin{array}{l}\text { H11: There is a } \\
\text { positive and } \\
\text { significant } \\
\text { relationship between } \\
\text { the ERP } \\
\text { Fit/Integration and } \\
\text { the ERP success }\end{array}$ & 11 & 1594 & 395,564 & 0,265 & 98,717 & 0,066 & 0,257 & 0,006 & $\mathbf{0 , 0 8 0}$ & $0,10-0,42$ & 0,060 & 0,244 & 0,829 & 0,908 & 0,305 & 0,008 & 0,092 & $0,12-0,48$ \\
\hline
\end{tabular}

$\mathrm{K}=$ Number of studies included; $\sum N_{i}=$ total sample size; $\bar{r}=$ correlation corrected for sampling error; $\rho=$ correlation corrected for both sampling error and error of measurement 


\section{Publication Bias and Heterogeneity}

\section{Failsafe $\mathrm{N}$ and the Funnel Plots}

To investigate the publication bias, and heterogeneity, we used the funnel plots and failsafe $\mathrm{N}$ (See Appendix). The funnel plots are defined by Wu and Lederer (2009) as a simple scatterplots of the Fisher's Z (horizontal axis) against the standard error (vertical axis). In the absence of bias, the funnel plot shows a symmetric inverted funnel shape with effect sizes and the inverse of the standard deviation. The publication bias may not be only identified by the funnel plots, other tests must be taken into account such as failsafe $\mathrm{N}$, that represents the number of additional studies (with null results) needed to render the results for that relationship non-significant at a pre-specified level ( $\mathrm{p} \leq 0.05$ ) (Wu \& Lederer, 2009). Both tests were computed for each factor to determine the publications bias. The Failsafe N shows the robustness of our results, it varies from 186 to 9509 with an average of 2112. They provide a confidence in the robustness of our meta-analysis (For example, we need 9509 additional studies with non-significant results to make the positive correlation between the system quality and the ERP success non-significant). In this study both funnel plots test and failsafe $\mathrm{N}$ show that the publication bias is not a problem.

\section{$\underline{\text { Heterogeneity Test }}$}

The heterogeneity or homogeneity test (Hedges, 1982; Rosenthal, 1995) could be used as a tool in deciding whether observed effect sizes are more variable than would be expected from sampling error alone (Wu \& Lederer, 2009). If there is a strong heterogeneity we have to search the moderator variables that could be considered as an explanation of the effect sizes variation. In our case we identified five main variables that could be considered as moderators: the geographic area and culture, the nature of the sector, the type of ERP software, the implementation phase, and the respondent function.

$\mathrm{I}^{2}=\frac{\mathrm{Q}-(\mathrm{K}-1)}{\mathrm{Q}}$ (Table 4), this index describes the percentage of variation across study that is due to heterogeneity rather than the chance, on the other hand it measures the variation that is not due to chance, it can take values from $0 \%$ to $100 \%$.

The Fisher's $\mathrm{Z}$ is computed by normalizing the correlation coefficients using the following formula: Fisher's $\mathrm{z}=0.5 \times \ln \frac{1+r}{1-r}$; then to calculate the weighted average $\mathrm{z}: \bar{z}=\frac{\sum n_{i} z_{i}}{\sum n_{i}}$; where $n_{i}$ is the sample size in study $i$. Finally, the $\mathrm{Q}$ statistic is computed by using the following formula: $Q=\sum\left(n_{I}-3\right)\left(z_{i}-\bar{z}\right)^{2}$ (Hedges, 1982; Rosenthal, 1995; Wu \& Lederer, 2009).

\section{DISCUSSION, IMPLICATIONS, AND CONCLUSION}

\section{Research Implications}

This study provides both theoretical backgrounds and empirical contribution to understand the factors that impact the ERP project success, this impact was measured in three levels of performance, individual, group, and organization. Thus, this study proposes a new taxonomy of the critical success factors and explains the ERP system success process using a strong theoretical foundations, mathematical theory of communication, diffusion innovation theory and AST (Adaptive Structuration Theory). The theoretical model developed in this work explains the ERP system success from two main dimensions, a causal dimension and a process dimension. The first one highlights the variables that contribute on the ERP system adoption and use, based on diffusions of innovations theory (Rogers, 1984). The second sheds the light on the process of the ERP system success through the explanation of interaction between organizational, individual, and technological variables based on the one hand on the mathematical theory of communication to explain how the system quality output impacts the individual and organizational performance (Weaver \& Shannon, 1949; Mason, 1978), and on the other hand on the AST (DeSanctis \& Poole, 1994) to explain the interaction between the human actors (ERP Users) and the technology, and how this later leads to improve the efficiency, quality and performance. The theoretical model developed in this study is appropriated to the ERP system; it takes into account the features of both implementation and use of the ERP system. Because, the ERP system is considered as a project including different stakeholders, organization involvement, user involvement, 
vendor and consultant involvement, its success depends on the collaboration between all the organization partners. Thus, the model explains how the organizational, technological, and environmental critical factors contribute to the ERP system adoption and use, which is considered as a synonymous of the ERP system quality. Then, the model shows the quality output represented by data and information quality, and how this later affects the performance and the efficiency. The definition of the success adopted in this model reveals that the success is considered as a correspondence and an interaction (Lyytinen \& Hirscheim, 1987). The correspondence highlights the fit between the ERP system and the organization objectives that leads to improve the organizational performance. The interaction success represents the positive user attitudes toward the ERP system, which contribute to improve both individual and workgroup performance.

\section{Managerial Implications}

This research work provides a new tool to practitioners enabling them a better understanding of the ERP system success project. Information system managers, top management, and ERP users need to understand the implication of their actions in the success process and how they contribute in the performance improvement. Thus, this work seeks to highlight the vendor and consultants contributions to perform the ERP project. To face more than three quarters of unsuccessful ERP project, organizations need to be able to evaluate the contribution of each CSF in the ERP life cycle. This need leads us to investigate this question by developing a new model that explain the relationships between the ERP partners on the one hand and propose the main factors to succeed the ERP project on the other. Eleven significant CSF were identified in this study and classified by the magnitude of effect sizes (Lipsey \& Wilson, 2004) given by every one based on a robustness methodology tests. This study offers a practical understanding for organization to determining the CFS's of complex information system such as the ERP system.

While we classify the effect sizes of the eleven CSF's by the strength of relationships using three main categories of taxonomy, strong, moderate, and weak. This taxonomy by the relationship importance between the constructs gives a clear vision to IS managers.

\section{Conclusion, Limitation, and Perspectives}

The meta-analysis methodology is a recent tool considered as a subject of many critics (Laroche \& Soulez, 2012). This methodology has shown its robustness in some fields like psychology and medicine. However, in management science there are a few numbers of researchers that use this methodology despite its importance and the reliability of its results, but this methodology requires a good knowledge of statistical tools and a detailed explanation of each step in the process of collecting, selecting, and coding studies.

We stress that this work is considered as the first one that tries to meta-analyze quantitatively the CSF's of ERP Success and attempts to summarize all the existing empirical researches in one study using a meta-analysis methodology. We have empirically validated our theoretical model that we proposed; and we found that our entire hypotheses were supported. Factors that we identified contribute to the ERP success. However, this contribution changes from one factor to another, but all the relationships are significant between the factors that we selected and the ERP Success. The Critical Factors of ERP system success in both pre-implementation and post-implementation phases are significant. However, some factors were found more significant than others, the factors with a high significant magnitude explain a very important role in the ERP system success and they need an important investment by organization to improve their benefits from the ERP System implementation.

This work provides important findings regarding the ERP system success; it also proposes and explains the contribution of the CSF's in the performance improvement. However, there are some limitations of this study that should be emphasized:

Firstly, the methodology used in our study: The meta-analysis methodology as a new technique using only a quantitative resultants stays a subject of many critics in information system field. It can only be performed on research that performs quantitative analysis; qualitative or conceptual works must be excluded (Petter \& McLean, 2009). Additionally, the number of studies found and used in this work is not to large, it could be considered as a limit of work results. 
Secondly, the performance measurement levels used in this study. Previous research using a meta-analysis methodology, delineate their level of analysis to only one level of measurement, for example organizational level of performance (Kirca et al., 2005; Petter \& McLean, 2009). In this study we use three levels of performance measurement: individual, group, and organizational performance.

Thirdly, the moderator factors (contingency factors) are not included in our meta-analysis with a quantitative analysis (subgroup analysis or bootstrap technics) to better understand some sources of heterogeneity. This last point should be considered as a main idea for future research to provide a new understanding of the role of the contingency factors in the ERP system Success.

\section{AUTHOR INFORMATION}

Abdesamad Zouine, CRCGM, Université d'Auvergne, Clermont-Ferrand, France E-mail: zouine.abdessamad@gmail.com (Corresponding author)

Pierre Fenies, CEROS, Université Paris X Nanterre, Paris, France.

\section{REFERENCES}

1. Al-Mashari, M., Al-Mudimigh, A., \& Zairi, M. (2003). Enterprise resource planning: A taxonomy of critical factors. European Journal of Operational Research, 146(2), 352-364.

2. Amoako-Gyampah, K. (2007). Perceived usefulness, user involvement and behavioral intention: An empirical study of ERP implementation. Computers in Human Behavior, 23(3), 1232-1248.

3. Bernroider, E. W. N. (2008). IT governance for enterprise resource planning supported by the DeLoneMcLean model of information systems success. Information \& Management, 45(5), 257-269.

4. Bernroider, E. W. N., Wong, C. W. Y., \& Lai, K. (2014). From dynamic capabilities to ERP enabled business improvements: The mediating effect of the implementation project. International Journal of Project Management, 32(2), 350-362.

5. Bradford, M., \& Florin, J. (2003). Examining the role of innovation diffusion factors on the implementation success of enterprise resource planning systems. International Journal of Accounting Information Systems, 4(3), 205-225.

6. Candra, S. (2012). ERP implementation success and knowledge capability. Procedia - Social and Behavioral Sciences, 65, 141-149.

7. Chand, D., Hachey, G., Hunton, J., Owhoso, V., \& Vasudevan, S. (2005). A balanced scorecard based framework for assessing the strategic impacts of ERP systems. Computers in Industry, 56(6), 558-572.

8. Chau, P. Y. K. (1999). On the use of construct reliability in MIS research: A meta-analysis. Information \& Management, 35(4), 217-227.

9. Chien, S.-W., Hu, C., Reimers, K., \& Lin, J.-S. (2007). The influence of centrifugal and centripetal forces on ERP project success in small and medium-sized enterprises in China and Taiwan. International Journal of Production Economics, 107(2), 380-396.

10. Choi, D. H., Kim, J., \& Kim, S. H. (2007). ERP training with a web-based electronic learning system: The flow theory perspective. International Journal of Human-Computer Studies, 65(3), 223-243.

11. Chou, J.-S., \& Hong, J.-H. (2013). Assessing the impact of quality determinants and user characteristics on successful enterprise resource planning project implementation. Journal of Manufacturing Systems, 32(4), 792-800.

12. Chou, S.-W., \& Chang, Y.-C. (2008). The implementation factors that influence the ERP (enterprise resource planning) benefits. Decision Support Systems, 46(1), 149-157.

13. Chung, B. Y., J. Skibniewski, M., C. Lucas Jr, H., \& Kwak, Y. H. (2008). Analyzing enterprise resource planning system implementation success factors in the engineering-construction industry. Journal of Computing in Civil Engineering, 22(6), 373-382.

14. Davenport, T. (1998). Putting the enterprise into the enterprise system. Harvard Business Review, 76(4), 121-131.

15. Davis, F. D. (1989a). Perceived usefulness, perceived ease of use, and user acceptance of information technology. MIS Quarterly, 13(3), 318-340. 
16. Davis, F. D. (1989b). User acceptance of computer technology: a comparison of two theoretical models. Management Science, 35(8), 982-1003.

17. DeLone, W. H., \& McLean, E. R. (1992). Information systems success: The quest for the dependent variable. Information Systems Research, 3(1), 6-95.

18. DeLone, W. H., \& McLean, E. R. (2003). The DeLone and McLean model of information systems success: A ten-year update. The Delone and McLean model of information on system success. Journal of Management Information Systems, 19(4), 9-30.

19. DeSanctis, G., \& Poole, M. S. (1994). Capturing the complexity in advanced technology use: Adaptive structuration theory. Organization Science, 15(2), 121-147.

20. Ehie, I. C., \& Madsen, M. (2005). Identifying critical issues in enterprise resource planning (ERP) implementation. Computers in Industry, 56(6), 545-557.

21. Finney, S., \& Corbett, M. (2007). ERP implementation: A compilation and analysis of critical success factors. Business Process Management Journal, 13(3), 329-347.

22. Fui-hoon nah, F., \& Delgado, S. (2006). Critical success factors for enterprise resource planning implementation and upgrade. Journal of Computer Information Systems, Special Issue, 99-113.

23. Gable, G. G., Sedera, D., \& Chan, T. (2003). Enterprise systems success: A measurement model. In Proceedings of the 24th International Conference on Information Systems Association for Information Systems (pp. 576-591). Seattle, Washington. Retrieved from http://eprints.qut.edu.au/4743/1/4743.pdf

24. Garcia-Sanchez, N., \& Pérez-Bernal, L. E. (2007). Determination of Critical success factors in implementing an ERP system: A field study in Mexican enterprises. Information Technology for Development, 13(3), 293-303.

25. Gorla, N., \& Lin, S.-C. (2010). Determinants of software quality: A survey of information systems project managers. Information and Software Technology, 52(6), 602-610.

26. Grant, D., Hwang, Y., \& Tu, Q. (2013). An empirical investigation of six levels of enterprise resource planning integration. Computers in Human Behavior, 29(6), 2123-2133.

27. Hedges, L. V. (1982). Estimation of effect size from a series of independent experiments. Psychological Bulletin, 92(2), 490-499.

28. Hong, K.-K., \& Kim, Y.-G. (2002). The critical success factors for ERP implementation: An organizational fit perspective. Information \& Management, 40(1), 25-40.

29. Hunter, J. E., Schmidt, F. L., \& Jackson, G. B. (1982). Meta-analysis: Cumulating research findings across studies (Vol. 4).

30. Ifinedo, P. (2011). Examining the influences of external expertise and in-house computer/IT knowledge on ERP system success. Journal of Systems and Software, 84(12), 2065-2078.

31. Ifinedo, P., \& Nahar, N. (2006). Quality, impact and success of ERP systems: A study involving some firms in the Nordic-Baltic region. Journal of Information Technology Impact, 6(1), 19-46.

32. Ifinedo, P., Rapp, B., Ifinedo, A., \& Sundberg, K. (2010). Relationships among ERP post-implementation success constructs: An analysis at the organizational level. Computers in Human Behavior, 26(5), 11361148.

33. Irani, Z. (2002). Information systems evaluation: navigating through the problem domain. Information \& Management, 40(1), 11-24.

34. Irani, Z., \& Love, P. E. D. (2008). Evaluating information systems public and private sector. Elsevier.

35. Irani, Z., Sharif, A., Kamal, M. M., \& Love, P. E. D. (2014). Visualising a knowledge mapping of information systems investment evaluation. Expert Systems with Applications, 41(1), 105-125.

36. Kaplan, R. S., \& Norton, D. P. (1992). The balanced scorecard - Measures that drive business perfomance. Harvard Business Review, January-February(70), 71-79.

37. Kirca, A. H., Jayachandran, S., \& Bearden, W. O. (2005). Market orientation: A meta-analytic review and assessment of its antecedents and impact on performance. Journal of Marketing, 69, 24-41.

38. Koh, S. C. L., Gunasekaran, A., \& Goodman, T. (2011). Drivers, barriers and critical success factors for ERPII implementation in supply chains: A critical analysis. The Journal of Strategic Information Systems, 20(4), 385-402.

39. Kwahk, K.-Y., \& Lee, J.-N. (2008). The role of readiness for change in ERP implementation: Theoretical bases and empirical validation. Information \& Management, 45(7), 474-481.

40. Lapiedra, R., Alegre, J., \& Chiva, R. (2011). The importance of management innovation and consultant services on ERP implementation success. The Service Industries Journal, 31(12), 1907-1917. 
41. Laroche, P., \& Soulez, S. (2012). La méthodologie de la méta-analyse en marketing. Recherche et Applications En Marketing, 27(1), 79-105.

42. Law, C. C. H., \& Ngai, E. W. T. (2007). ERP systems adoption: An exploratory study of the organizational factors and impacts of ERP success. Information \& Management, 44(4), 418-432.

43. Lee, Y. W., Strong, D. M., Kahn, B. K., \& Wang, R. Y. (2002). AIMQ: A methodology for information quality assessment. Information \& Management, 40(2), 133-146.

44. Lipsey, M. W., \& Wilson, D. B. (2004). Practical meta-analysis (Sage publications., Vol. 49).

45. Lyytinen, K., \& Hirschheim, R. (1987). Information systems failures - A survey and classification of the empirical literature. Oxford Surveys in Information Technology, 4, 257-309.

46. Markus, M. L., \& Tanis, C. (2000). The enterprise system experience-From adoption to success (Vols. 136).

47. Mason, R. O. (1978). Measuring information output: A communication systems approach. Information \& Management, 1(4), 219-234.

48. Myers, B. L., Kappelman, L. A., \& Prybutok, V. R. (1997). A comprehensive model of assessing the quality and productivity of the information system function: Toward a theory of information systems assessment. Information Resources Management Journal, 10(1), 6-25.

49. Ngai, E. W. T., Law, C. C. H., \& Wat, F. K. T. (2008). Examining the critical success factors in the adoption of enterprise resource planning. Computers in Industry, 59(6), 548-564.

50. Nicolaou, A. I., \& Bhattacharya, S. (2006). Organizational performance effects of ERP systems usage: The impact of post-implementation changes. International Journal of Accounting Information Systems, 7(1), 18-35.

51. Petter, S., \& McLean, E. R. (2009). A meta-analytic assessment of the DeLone and McLean IS success model: An examination of IS success at the individual level. Information \& Management, 46(3), 159-166.

52. Plant, R., \& Willcocks, L. (2007). Critical success factors in international ERP implementations: a case research approach. Journal of Computer Information Systems, 60-70.

53. Ram, J., Corkindale, D., \& Wu, M.-L. (2013). Implementation critical success factors (CSFs) for ERP: Do they contribute to implementation success and post-implementation performance? International Journal of Production Economics, 144(1), 157-174.

54. Ram, J., Wu, M.-L., \& Tagg, R. (2013). Competitive advantage from ERP projects: Examining the role of key implementation drivers. International Journal of Project Management, 32(4), 663-675.

55. Rogers, E. M. (1983). Diffusion of innovations (3rd ed., Vols. 1-447). United States of America: Free Press.

56. Rosemann, M., \& Wiese, J. (1999). Measuring the performance of ERP software - A balanced scorecard approach. In Proc. 10th Australasian Conference on Information Systems (pp. 773-784). Retrieved from http://citeseerx.ist.psu.edu/viewdoc/download?doi=10.1.1.4.9176\&rep=rep1\&type=pdf

57. Rosenthal, R. (1995). Writing Meta-Analytic Reviews. Psychological Bulletin, 118(2), 183-192.

58. Scott, J. E., \& Walczak, S. (2009). Cognitive engagement with a multimedia ERP training tool: Assessing computer self-efficacy and technology acceptance. Information \& Management, 46(4), 221-232.

59. Seddon, P. (1997). A respecification and extension of the DeLone and McLean model of IS success. Information Systems Research, 8(3), 240-253.

60. Sedera, D., \& Gable, G. G. (2010). Knowledge management competence for enterprise system success. The Journal of Strategic Information Systems, 19(4), 296-306.

61. Shang, S., \& Seddon, B. P. (2002). Assessing and managing the benefits of enterprise systems: The business manager's perspective. Information Systems Journal, 12(4), 271-299.

62. Shih, Y.-Y., \& Huang, S.-S. (2009). The actual usage of ERP systems: An extended technology acceptance perspective. Journal of Research and Practice in Information Technology, 41(3), 263-276.

63. Somers, T. M., \& Nelson, K. (2001). The impact of critical success factors across the stages of enterprise resource planning implementation. In Proceedings of the 34th Hawaii international conference on System Sciences. Hawaii USA.

64. Song, X., \& Letch, N. (2012). Research on IT/IS evaluation: A25 year review. The Electronic Journal Information Systems Evaluation, 15(3), 276-287.

65. Stefanou, C. J., (2001). A framework for the ex-ante evaluation of ERP software. European Journal of Information Systems, 10, 204-2015. 
66. Sternad, S., \& Bobek, S. (2012). Success factors for dynamics NAV solution implementation: What matters and how. Journal of Integrated Enterprise Systems, 1(1), 18-33.

67. Sun, Y., Bhattacherjee, A., \& Ma, Q. (2009). Extending technology usage to work settings: The role of perceived work compatibility in ERP implementation. Information \& Management, 46(6), 351-356.

68. Tsai, W.-H., Hsu, P.-Y., \& Cheng, J. M.-S. (2006). An AHP approach to assessing the relative importance weights of ERP performance measures. International Journal of Management \& Enterprise Development, 3(4), 351-375.

69. Tsai, W.-H., Lee, P.-L., Shen, Y.-S., \& Lin, H.-L. (2012). A comprehensive study of the relationship between enterprise resource planning selection criteria and enterprise resource planning system success. Information \& Management, 49(1), 36-46.

70. Uwizeyemungu, S., \& Raymond, L. (2010). Linking the effects of ERP to organizational performance: Development and initial validation of an evaluation method. Information Systems Management, 27(1), 2541. doi:10.1080/10580530903455122

71. Velcu, O. (2010). Strategic alignment of ERP implementation stages: An empirical investigation. Information \& Management, 47(3), 158-166. d

72. Venkatesh, V., \& Davis, F. D. (2000). A theoretical extension of the technology acceptance model: Four longitudinal field studies. Management Science, 46(2), 186-204.

73. Venkatesh, V., Morris, M. G., Davis, G. B., \& Davis, F. D. (2003). User acceptance of information technology: toward a unified view1. MIS Quarterly, 27(3), 425-478.

74. Wang, E. T. G., \& Chen, J. H. F. (2006). The influence of governance equilibrium on ERP project success. Decision Support Systems, 41(4), 708-727.

75. Wang, E. T. G., Shih, S.-P., Jiang, J. J., \& Klein, G. (2008). The consistency among facilitating factors and ERP implementation success: A holistic view of fit. Journal of Systems and Software, 81(9), 1609-1621.

76. Weaver, W., \& Shannon, C. (1949, September). The mathematical theory of communication.

77. Wu, J., \& Lederer, A. (2009). A meta-analysis of the role of environment-based voluntariness in information technology acceptance. MIS Quarterly, 33(2), 419-432.

78. Wu, K., Zhao, Y., Zhu, Q., Tan, X., \& Zheng, H. (2011). A meta-analysis of the impact of trust on technology acceptance model: Investigation of moderating influence of subject and context type.

International Journal of Information Management, 31(6), 572-581.

79. Yoon, C. (2009). The effects of organizational citizenship behaviors on ERP system success. Computers in Human Behavior, 25(2), 421-428.

80. Zhang, Lee, Zhang, \& Banerjee. (2002). Critical Success factors of enterprise resource planning systems implementation success in China. In Proceedings of the 36th Hawaii International Conference on System Sciences. Hwaii USA: IEEE.

81. Zhu, Y., Li, Y., Wang, W., \& Chen, J. (2010). What leads to post-implementation success of ERP? An empirical study of the Chinese retail industry. International Journal of Information Management, 30(3), 265-276. 


\section{APPENDIX}

\section{Individual Impact}

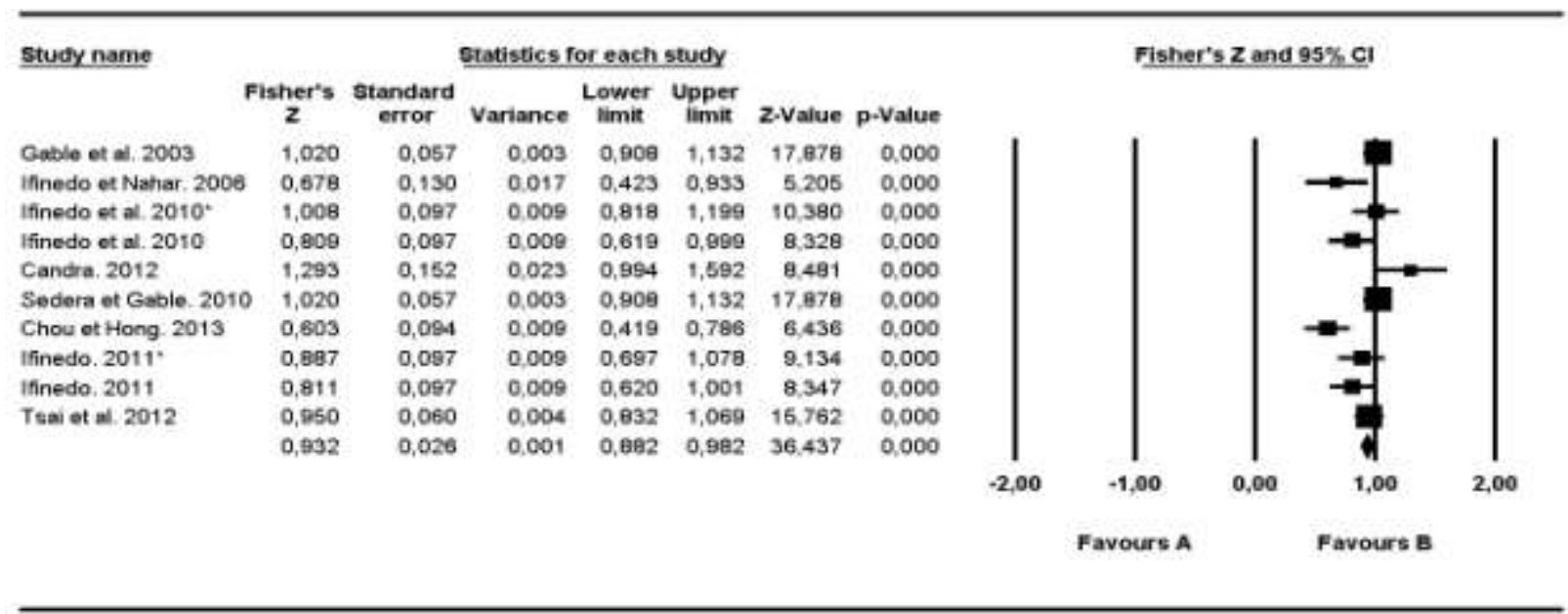

\begin{tabular}{|c|c|c|c|c|c|c|c|c|c|c|c|}
\hline \multirow[t]{2}{*}{ Nodel } & \multirow[t]{2}{*}{ Sudyname } & \multicolumn{7}{|c|}{ Staistics for each study } & \multirow{2}{*}{$\begin{array}{c}\text { Semple size } \\
\text { Total }\end{array}$} & \multirow{2}{*}{$\begin{array}{l}\text { Weight (Fwed) } \\
\text { Relative weight }\end{array}$} & \multirow{2}{*}{$\begin{array}{l}\text { Weight (Randomi } \\
\text { Relakve weight }\end{array}$} \\
\hline & & Fisher's Z & $\begin{array}{l}\text { Sandard } \\
\text { error }\end{array}$ & Variance & Lover inth & Unoer imt & 2-value & D. Vale & & & \\
\hline & Gable et a. 2003 & 1020 & 0,057 & 0,003 & 0.968 & 1,132 & 17,878 & 0,000 & 310 & 20,05 & $12.66 \rrbracket$ \\
\hline & Fnedo et Naher 2006 & 0678 & 0,130 & 0,017 & 0,423 & 0933 & 5.206 & 0,000 & 62 & 3.861 & 7.681 \\
\hline & Ineso et a $2010^{\circ}$ & 1008 & 0.097 & 0,009 & 0.818 & 1,199 & 10.380 & $0, \infty 0$ & 109 & 6.931 & 9651 \\
\hline & Ifineso et al: 2010 & 0.200 & Q.097 & 0,009 & 0.619 & 0.989 & 8,328 & 0,000 & 109 & 6.931 & 9681 \\
\hline & Condra. 2012 & 1.290 & 0,152 & 0,003 & 0.994 & $150 \%$ & 8431 & 0,000 & $\$ 8$ & 2.811 & 6.291 \\
\hline & Sedera el Cable 2010 & 1020 & 0,067 & 0,000 & 0,908 & 1.132 & 17,378 & 0,000 & 310 & 20,05 & 12,66 \\
\hline & Chou et Hong 2013 & 0,600 & 0,004 & 0,009 & 0.419 & 0,726 & 6.438 & 0,000 & 117 & $7,46 \mid$ & 9,901 \\
\hline & Inedo $2011^{\circ}$ & 0.887 & 0,097 & 0,009 & 0.697 & 1078 & 9134 & 0,000 & 109 & 6,931 & 9.65 \\
\hline & Inedo 2011 & 0,811 & 0,097 & 0,009 & 0.620 & 1001 & 8347 & 0,000 & 109 & 6931 & 9,65 \\
\hline & Tsei af a 2012 & 0.950 & 0,060 & 0,004 & 0.832 & 1,069 & 15.702 & 0,000 & 278 & 17,99 ] & 12,43 \\
\hline Fhed & & 0.988 & 0,026 & 0,001 & 0.82 & 0982 & 36.437 & 0,000 & & & \\
\hline Random & & $0.90 ?$ & 0.050 & 0,002 & 0,808 & 1006 & 18.148 & 0,000 & & & \\
\hline
\end{tabular}




\section{Funnel Plot of Standard Error by Fisher's Z}

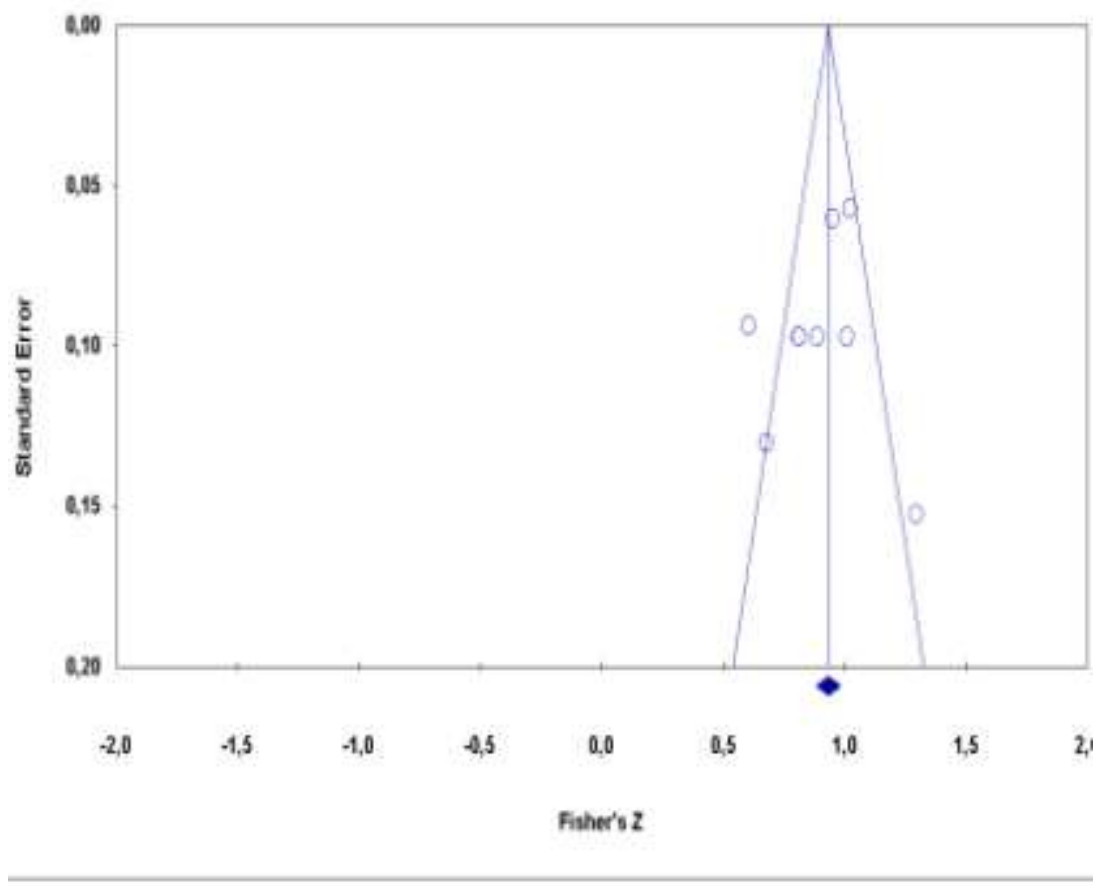

\section{Classic fail-safe $\mathrm{N}$}

$\begin{array}{lr}\text { Z-value for observed studies } & 34,09829 \\ \text { P-value for observed studies } & 0,00000 \\ \text { Alpha } & 0,05000 \\ \text { Tais } & 2,00000 \\ Z \text { for alpha } & 1,95996 \\ \text { Number of observed studies } & 10,00000 \\ \text { Number of missing studies that would bring p-value to > alpha } & 3017,00000\end{array}$

\section{Orwin's fail-safe $\mathrm{N}$}

Fisher's Z in observed studies

0.93183

Critenion for a 'trival' fisher's z

0,00000

Mean fisher's $z$ in missing studies

0,00000 


\section{Information Quality}

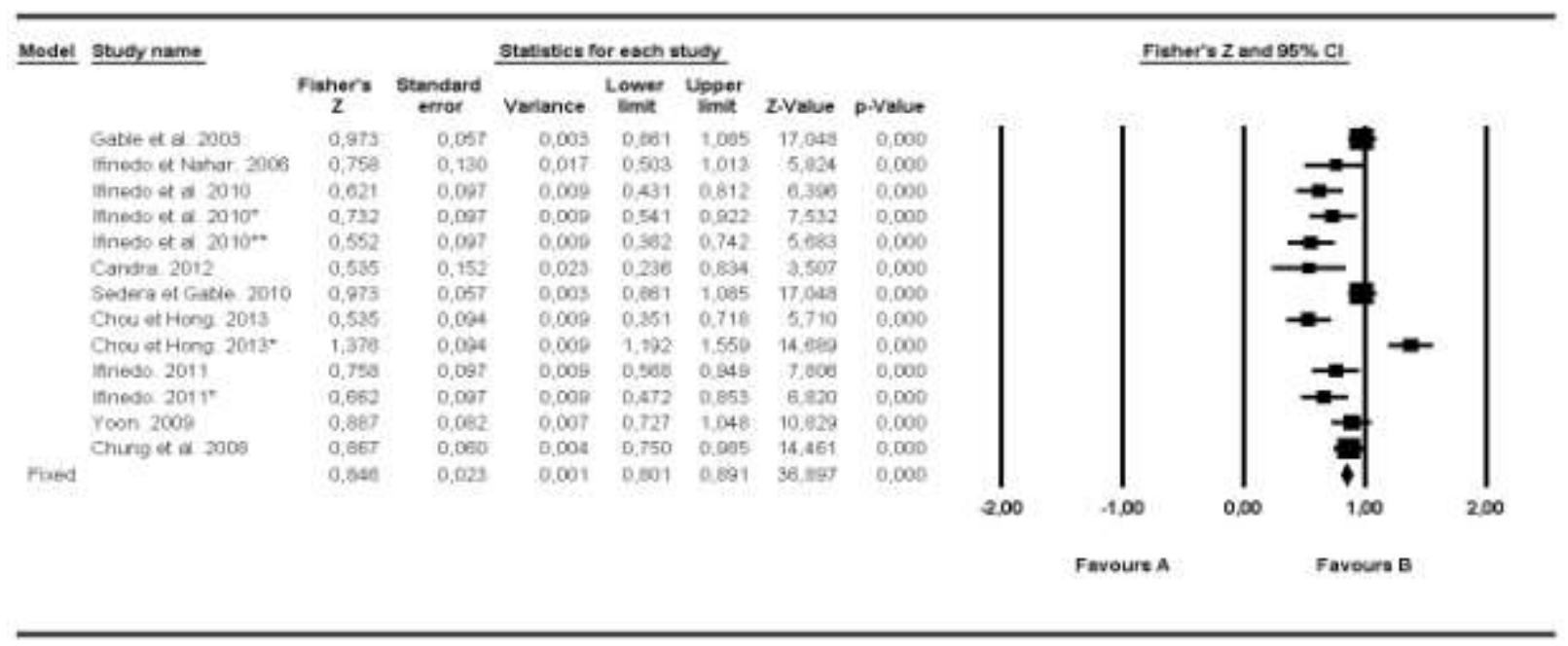

\begin{tabular}{|c|c|c|c|c|c|c|c|c|c|c|}
\hline \multirow[t]{2}{*}{ Model } & \multirow[t]{2}{*}{ Study name } & \multicolumn{7}{|c|}{ Statstics for each study } & \multirow{2}{*}{$\begin{array}{l}\text { Weight (Foedi } \\
\text { Reiatve weight }\end{array}$} & \multirow{2}{*}{$\begin{array}{l}\text { Weght (Random } \\
\text { Recative wect't }\end{array}$} \\
\hline & & Fishers $z$ & $\begin{array}{l}\text { Standerd } \\
\text { error }\end{array}$ & Weriance & Lower imit & Upper int & 2-wate & D-value & & \\
\hline & Gable et al 2093 & 0,973 & 0.057 & 0,003 & 0,861 & 1,025 & 17,048 & 0,000 & 16,15 ] & 8711 \\
\hline & Ifredo et Nahar, 2006 & 0,758 & 0.130 & 0,017 & 0,500 & 1,013 & 5824 & 0,000 & 3.101 & 6.581 \\
\hline & ifredoet al 2010 & 0.621 & 0.097 & 0,009 & 0,431 & 0.812 & 6.398 & 0,000 & 5,581 & 7601 \\
\hline & Ifreda of al $2010^{\circ}$ & 0,732 & 0.097 & 0,009 & 0,541 & 0.922 & 7,532 & 0,000 & 5,581 & 7.601 \\
\hline & Ifneso et ai $2010^{\circ}$ & 0,552 & 0,097 & 0,009 & 0,362 & 0.742 & 5.683 & 0,000 & 5.681 & 7,601 \\
\hline & Candra 2012 & 0,535 & 0.152 & 0,023 & 0,236 & 0,834 & 3,507 & 0,000 & 2.26 & 5911 \\
\hline & Sedera et Gable. 2010 & 0,973 & 0.057 & 0,003 & 0,881 & 1,085 & 17,048 & 0,000 & $16,15 \mathbf{E}$ & 8.711 \\
\hline & Chou et Hong 2013 & 0,536 & 0.094 & 0,009 & 0,351 & 0,718 & 5,710 & 0,000 & $6, \infty \mathbf{I}$ & 7,701 \\
\hline & Chou et Hong 2013". & 1,376 & 0,094 & 0,009 & 1,192 & 1,559 & 14688 & 0.000 & $6, \infty 1$ & 7.701 \\
\hline & Ifnedo. 2011 & 0,758 & 0.097 & 0,009 & 0,568 & 0.949 & 7,806 & 0,000 & 5,581 & 7.601 \\
\hline & Ifnedo 2011 " & 0,662 & 0.097 & 0,009 & 0,472 & 0,853 & 6.820 & 0,000 & 5,581 & 7601 \\
\hline & Yoon. 2009 & 0,887 & 0,082 & 0,007 & 0.727 & 1.048 & 10.829 & 0,000 & 7.841 & 8.051 \\
\hline & Chung et al 2008 & 0,867 & 0,060 & 0,004 & 0,750 & 0,985 & 14.461 & 0,000 & $1462 \overline{0}$ & $8.64 \mathbf{I}$ \\
\hline Fibed & & 0,846 & 0,023 & 0,001 & 0,801 & 0.891 & 36,897 & 0,000 & & \\
\hline Random & & 0,797 & 0.061 & 0,004 & 0,678 & 0.916 & 13.158 & $0,0,00$ & & \\
\hline
\end{tabular}


Funnel Plot of Standard Error by Fisher's Z

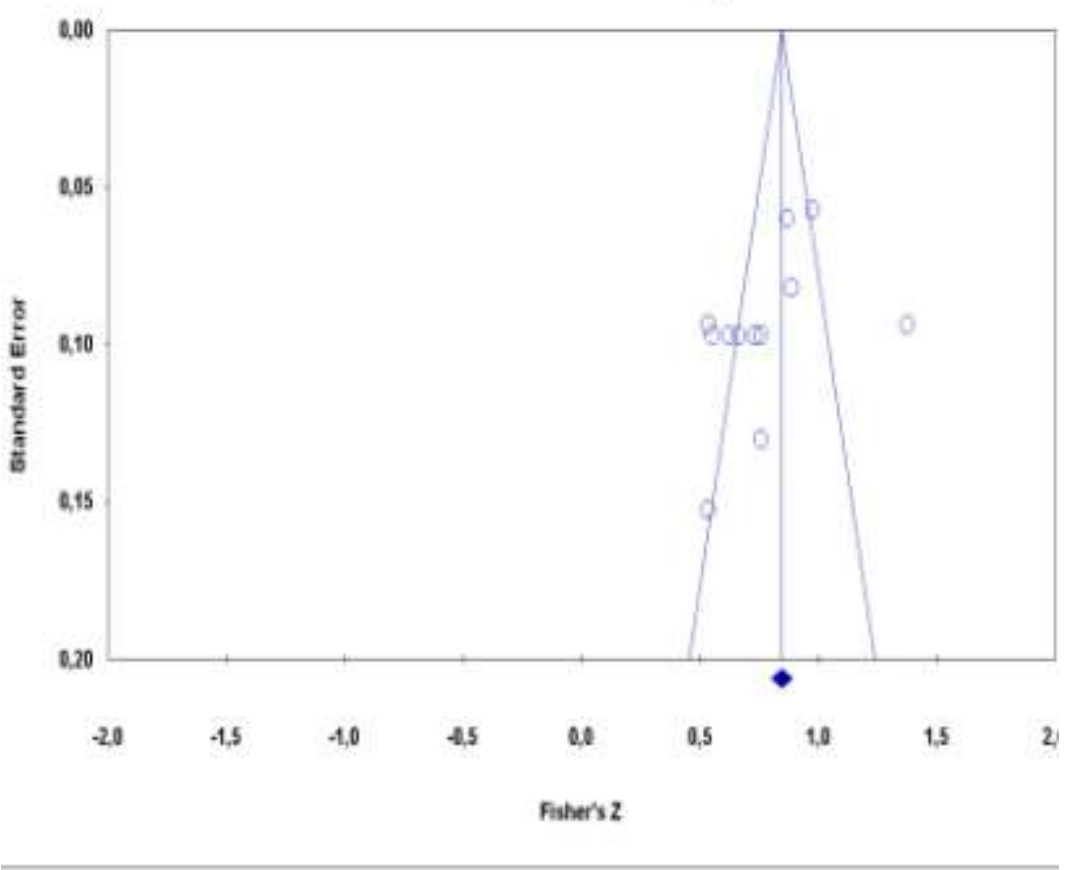

\section{Classic fail-safe $\mathrm{N}$}

Z-value for coserved studes

34.21149

P-value for observed studies

0.00000

Alpha

0,05000

Tals

200000

$Z$ for abha

1.95996

Number of coserved studes

13,00000

Number of missing studies that would bring p-value to > abha

3948,00000

\section{Orwin's fail-safe $\mathbf{N}$}

Fisher's $Z$ in observed studes

0.84624

Criterion for a 'trivial' fisher's $z$

0,00000

Mean fisher's $z$ in missing studies

0,00000 


\section{Workgroup Impact}

\begin{tabular}{|c|c|c|c|c|c|c|c|c|c|c|c|c|}
\hline \multirow[t]{2}{*}{ Study name } & \multicolumn{7}{|c|}{ Statistics for each study } & \multicolumn{5}{|c|}{ Fisher's $\mathrm{Z}$ and $95 \% \mathrm{Cl}$} \\
\hline & $\begin{array}{l}\text { Fisher's } \\
z\end{array}$ & $\begin{array}{c}\text { Standard } \\
\text { error }\end{array}$ & Variance & $\begin{array}{l}\text { Lower } \\
\text { limit }\end{array}$ & $\begin{array}{l}\text { Upper } \\
\text { limit }\end{array}$ & Z-Value & $\mathrm{p}$-Value & & & & & \\
\hline Ifinedo et Nahar. 2006 & 0,725 & 0,130 & 0,017 & 0,470 & 0,980 & 5,569 & 0,000 & | & I & I & & 1 \\
\hline Ifinedo et al. $2010^{\circ}$ & 0,809 & 0,097 & 0,009 & 0,619 & 0,999 & 8,328 & 0,000 & & & & & \\
\hline Ifinedo et al. 2010 & 0,867 & 0,097 & 0,009 & 0,677 & 1,058 & 8,929 & 0,000 & & & & & \\
\hline \multirow[t]{3}{*}{ Ifinedo. 2011} & 0,811 & 0,097 & 0,009 & 0,620 & 1,001 & 8,347 & 0,000 & & & & & \\
\hline & 0,813 & 0,052 & 0,003 & 0,712 & 0,914 & 15,780 & 0,000 & & & & & \\
\hline & & & & & & & & $-2,00$ & $-1,00$ & 0,00 & 1,00 & 2,00 \\
\hline
\end{tabular}

\begin{tabular}{|c|c|c|c|c|c|c|c|c|c|c|}
\hline \multirow[t]{2}{*}{ Model } & \multirow[t]{2}{*}{ Sudyrame } & \multicolumn{7}{|c|}{ Staistios ior each study. } & \multirow{2}{*}{$\begin{array}{l}\text { Weight (Fived) } \\
\text { Reafie meight }\end{array}$} & \multirow{2}{*}{$\begin{array}{l}\text { Weight (Random) } \\
\text { Reafive weight }\end{array}$} \\
\hline & & Fisher's Z & $\begin{array}{l}\text { Standard } \\
\text { erro }\end{array}$ & Varance & Louer imit & Upper int & Z-Vaue & D-Vaue & & \\
\hline & Ifnedo et Natar 2006 & 0,725 & 0,130 & 0,017 & 0,470 & 0,980 & 5.569 & 0,000 & $15,65 \square$ & 1565 \\
\hline & Ifinedo et al. $2010^{\circ}$ & 0,800 & 0,097 & 0,009 & 0,619 & 0,999 & 8,328 & 0,000 & 28,12 므 & 28.12 ] \\
\hline & Ifredo et al. 2010 & 0,867 & 0,097 & 0,009 & 0,677 & 1,058 & 8,929 & 0,000 & $28,12]$ & $28,12]$ \\
\hline & Inedo. 2011 & 0.811 & 0,097 & 0,009 & 0,620 & 1,001 & 8347 & 0,000 & $28,12 \square$ & $28,12 \square$ \\
\hline Fved & & 0,813 & 0,052 & 0,003 & 0,712 & 0.914 & 15,780 & 0,000 & & \\
\hline Random & & 0,813 & 0,052 & 0,003 & 0,712 & 0.914 & 15,780 & 0,000 & & \\
\hline
\end{tabular}

Funnel Plot of Standard Error by Fisher's Z

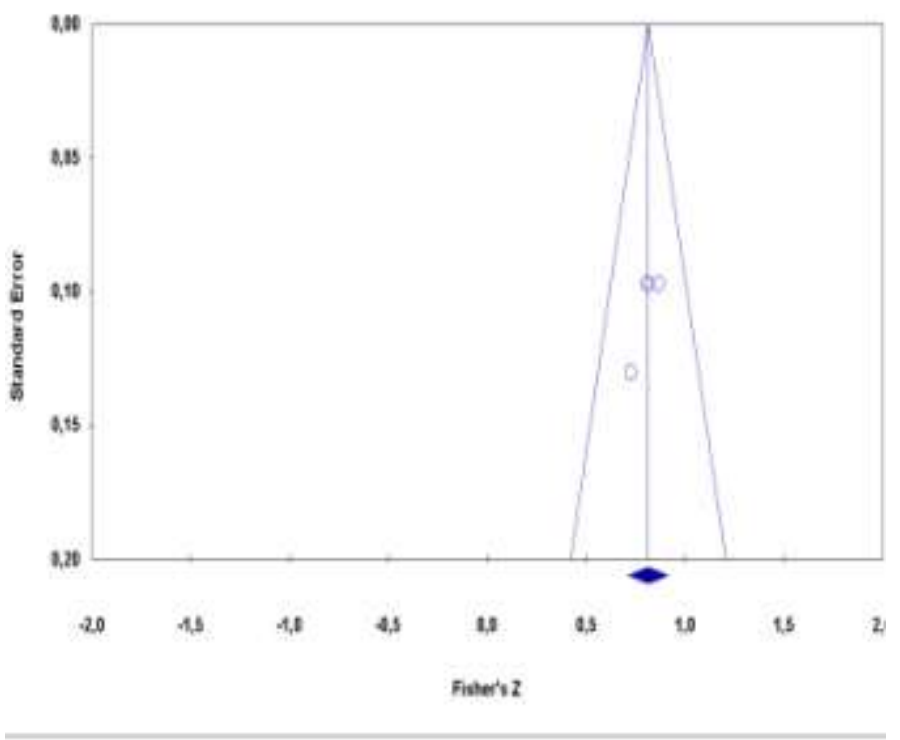

\section{Classic failsafe $\mathrm{N}$}

2-atue for coserveo studes

15,50092

Pustue tor coserved studes

0,00000

Apha

0.05000

200000

Tais

195996

4,00000

Number of cosenved studes

249.00000

Number of missng studes that woud bcreg p-velue io > apha

\section{Orwin's fail-safe $\mathrm{N}$}

Fishers 2 in observed studies

0.81272

Coterion for a twivar fsichers $z$

0.00000

Mean fisher's $z$ in missing studes 


\section{System Quality}

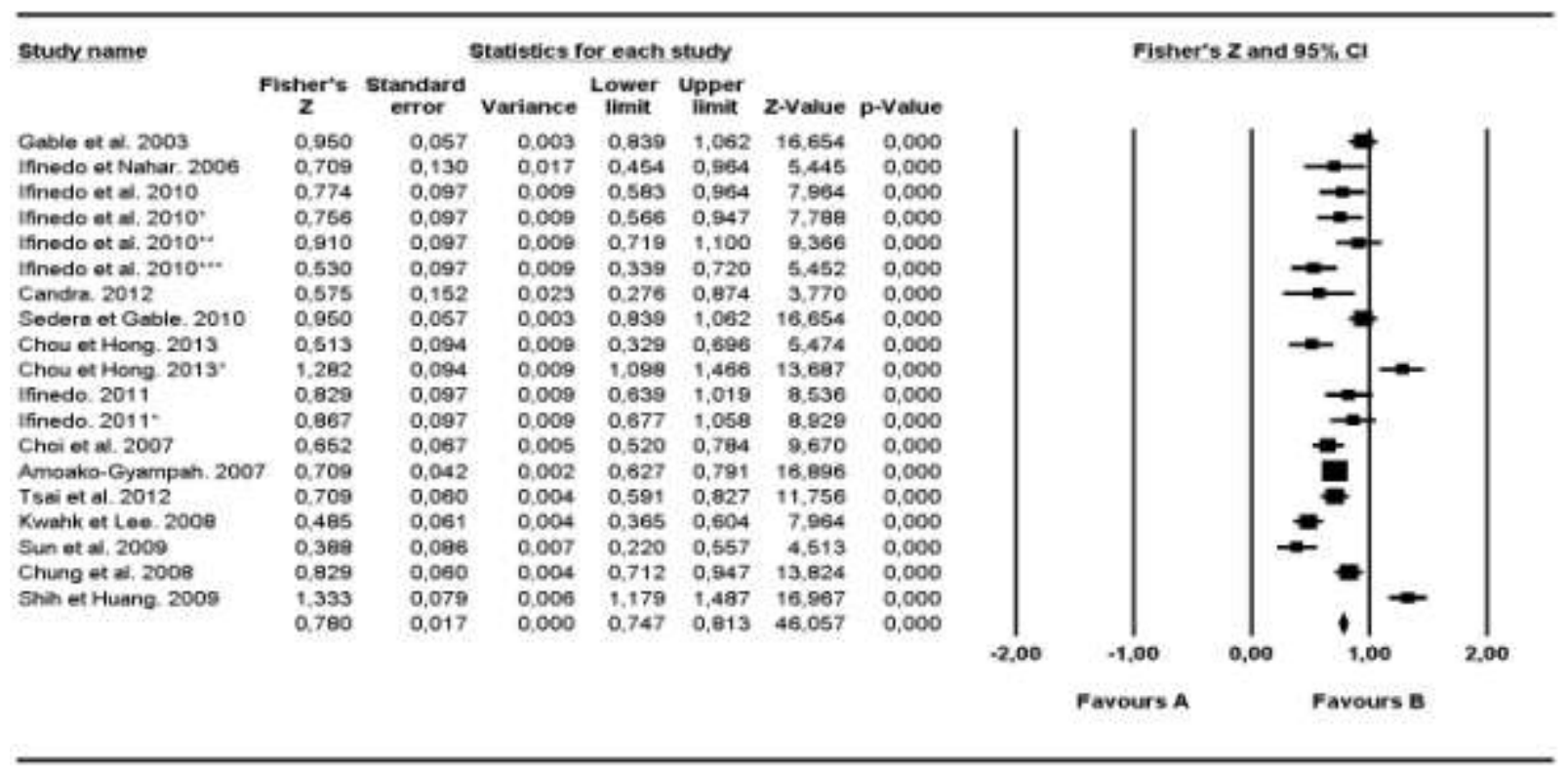

\begin{tabular}{|c|c|c|c|c|c|c|c|c|c|c|}
\hline \multirow[t]{2}{*}{ Mode: } & \multirow[t]{2}{*}{ study neme } & \multicolumn{7}{|c|}{ Statisles for texch study } & \multirow{2}{*}{$\begin{array}{l}\text { Weght (Fbod) } \\
\text { Felative wech }\end{array}$} & \multirow{2}{*}{$\begin{array}{l}\text { Weart (Random) } \\
\text { Relatien wooht }\end{array}$} \\
\hline & & Fisher's $z$ & $\begin{array}{l}\text { Standerd } \\
\text { entro }\end{array}$ & Whance & Lower innt & Uboer imt & $z$-vene & D-veve & & \\
\hline & Cabie et al 2003 & 0.960 & 0.057 & 0.003 & 0.839 & 1062 & 16.654 & 0,000 & B.80 1 & 5.721 \\
\hline & ithede et Nahar 3006 & 0.700 & 0.130 & 0.017 & 0.454 & 0.964 & 5445 & 0.000 & 1.69 & 4.491 \\
\hline & innede et al. 2010 & 0,774 & 0,007 & 0.009 & 0.583 & 0,964 & 7.964 & 0.000 & 3041 & 5.091 \\
\hline & Ifhesto at al. $2010^{\circ}$ & 0.756 & 0,097 & 0009 & 0,666 & 0.947 & 7,788 & 0,000 & 304 & 5,001 \\
\hline & ithodo et al. $2010^{\circ}$ & 0,010 & 0,097 & 0,000 & 0.710 & 1,100 & 2,396 & 0,000 & 3041 & 5,001 \\
\hline & Ithedo et at. 2010 tet & 0,630 & 0,000 & 0,000 & 0,330 & 0.720 & 5452 & 0,000 & $3.04 \mid$ & 5,031 \\
\hline & Candra 2012 & 0.575 & 0,152 & 0,023 & 0.276 & 0.874 & 3,770 & 0,000 & $1,23 \mid$ & 4,081 \\
\hline & Sedera et Gobie. 2010 & 0.960 & 0,057 & 0.003 & 0.839 & 1,062 & 16,654 & 0000 & BEO I & 5,721 \\
\hline & Onou et Hong 2013 & 0,613 & 0.094 & 0.009 & 0,329 & D,eOd & 5,474 & 0,000 & 3271 & $5.16 !$ \\
\hline & Cnou et Hong 2013 " & 1,282 & 0,004 & 0,000 & 1008 & 1,496 & 13687 & 0.000 & 3271 & 6.151 \\
\hline & imedo 2011 & 0,020 & 0.097 & 0.009 & 0.699 & 1,019 & 8.536 & 0.000 & 3041 & 5,091 \\
\hline & ithedo 2011 & 0.867 & 0.097 & 0.009 & 0.677 & 1.088 & 8,029 & 0000 & 3.041 & 5,091 \\
\hline & Ond ef a. 2007 & 0,052 & 0,087 & 0,008 & 0.520 & 0.754 & 9670 & 0,000 & 6.311 & 5.571 \\
\hline & Ameako Oyampan. 2007 & 0,700 & 0.042 & 0.002 & 0.627 & 0.791 & 16896 & 0,000 & 16.28 ] & 5.82 I \\
\hline & Tsar a a 2012 & 0.700 & 0,060 & 0.004 & 0,501 & 0.827 & 11.756 & 0000 & 7.881 & $5,67 \mathbf{I}$ \\
\hline & Whahk et Lee. 2008 & 0,485 & 0.061 & 0.004 & 0.305 & 0.604 & 7,964 & 0,000 & 7,741 & 5,671 \\
\hline & Sun et ai. 2000 & 0,388 & 0,086 & 0,007 & 0.220 & 0,507 & 4.813 & 0,000 & 3871 & 5.281 \\
\hline & Oxang et al 2008 & 0.820 & 0.060 & 0.004 & 0.712 & 0,947 & 13824 & $0, \infty 0$ & 7971 & 5.681 \\
\hline & Shh at Huang 2000 & 1.333 & 0.070 & 0.006 & 1.170 & 1.487 & 16957 & 0.000 & 4841 & 5,401 \\
\hline Foned & & 0.780 & 0,017 & 0.000 & 0.747 & 0.813 & 46.057 & 0.000 & & \\
\hline random & & $a, 779$ & 0.063 & 0,000 & 0.674 & 0.834 & 14.600 & 0.000 & & \\
\hline
\end{tabular}


Funnel Plot of Standard Error by Fisher's Z

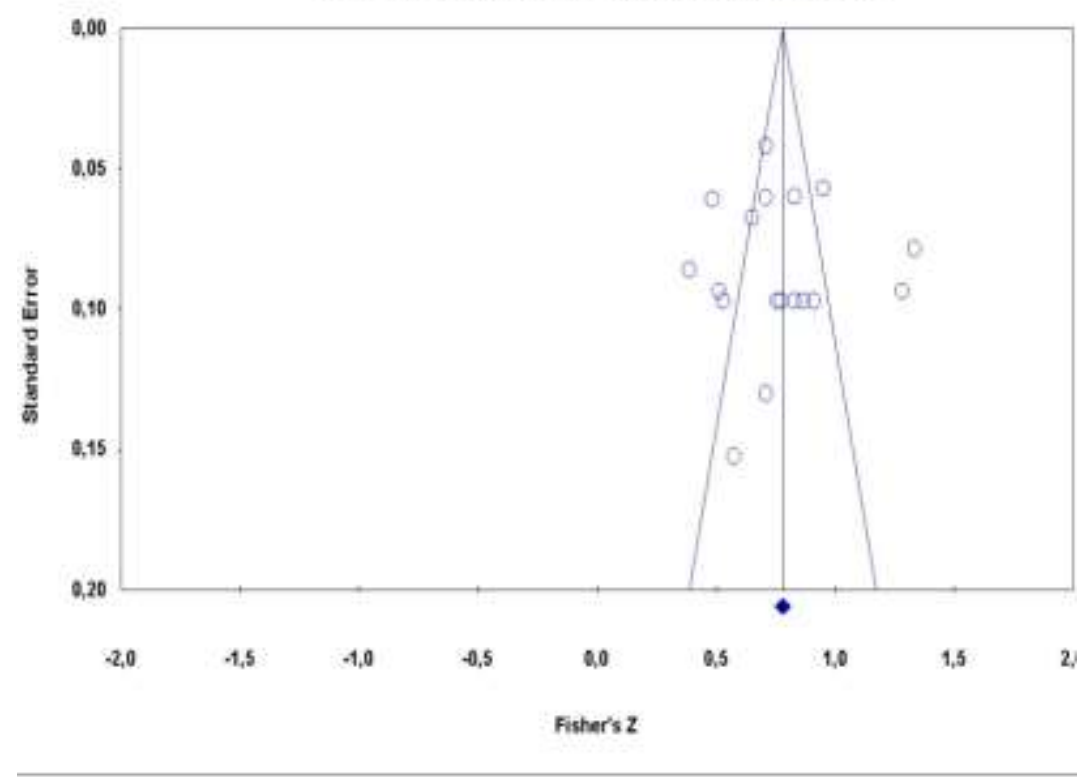

\section{Classic fail-safe $\mathrm{N}$}

$Z$-value for observed studies

43,88981

P-value for observed studies

0,00000

Alpha

0.05000

Tals

2,00000

$Z$ for alpha

1,95996

Number of observed studies

19,00000

Number of missing studies that would bring p-value to > alpha

9509,00000

\section{Orwin's fail-safe $\mathrm{N}$}

Fisher's $Z$ in observed studies

0.77985

Criterion for a 'twival' fisher's 2

0,00000

Mean fisher's $z$ in missing studies

0,00000 


\section{Organizational Impact}

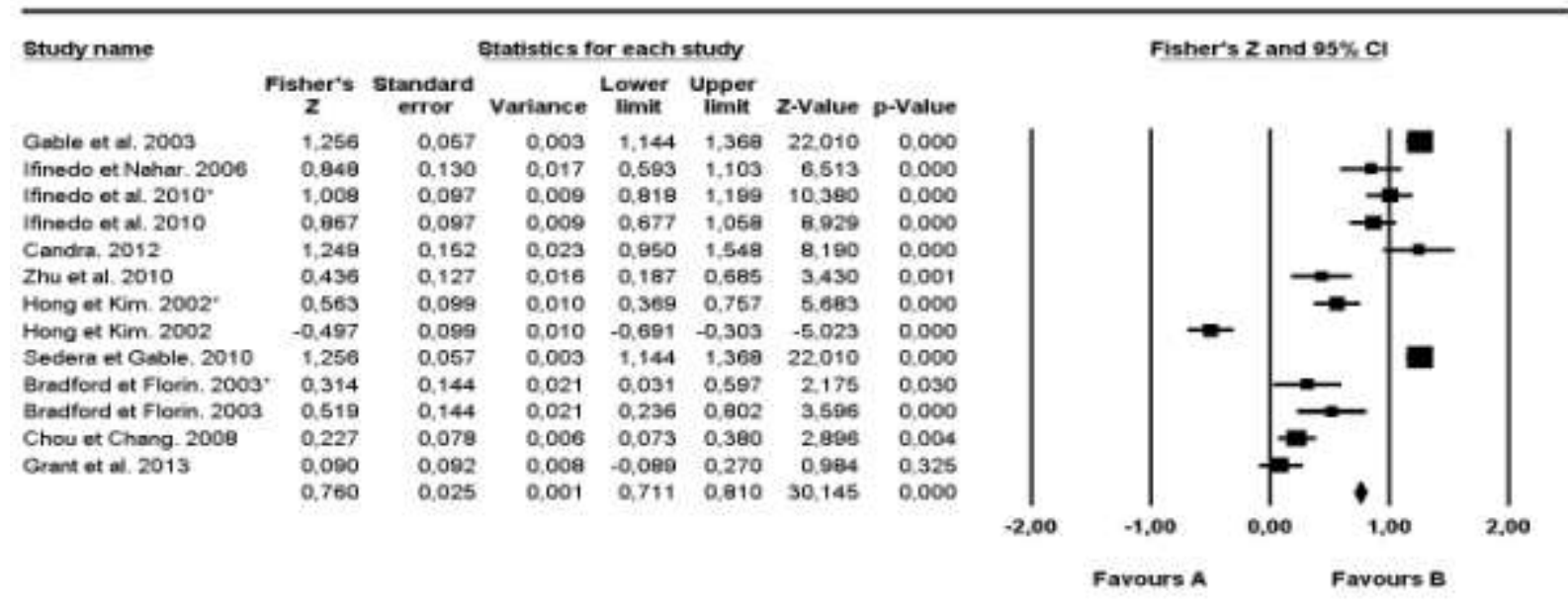

Meta Analysis

\begin{tabular}{|c|c|c|c|c|c|c|c|c|c|c|}
\hline \multirow[t]{2}{*}{ Model } & \multirow[t]{2}{*}{ Study name } & \multicolumn{7}{|c|}{ Statistics for each study } & \multirow{2}{*}{$\begin{array}{l}\text { Weicht (Flued) } \\
\text { Reiatwe woight }\end{array}$} & \multirow{2}{*}{$\begin{array}{l}\text { Weight ( Random } \\
\text { fredative woight }\end{array}$} \\
\hline & & Fisher's $Z$ & $\begin{array}{l}\text { Standard } \\
\text { erro }\end{array}$ & Variance & Lower ims & Upoer imit: & 2-volue & D-Value & & \\
\hline & Gable et al 2003 & 1.256 & 0,057 & $0, \infty 03$ & 1,144 & 1,368 & 22,010 & 0,000 & 1953 远 & 7,901 \\
\hline & ffredo ef Nahar: 2066 & 0.848 & 0.130 & 0,017 & 0,593 & 1,103 & 6,513 & 0.000 & 3.751 & 7,581 \\
\hline & Ifnedo et al $2010^{+}$ & 1.005 & 0.097 & 0.003 & 0.818 & 1,199 & 10,380 & 0,000 & 6.741 & 7,75 I \\
\hline & Ifnedo et al 2010 & 0.867 & 0,097 & 0.009 & 0.677 & 1,068 & B.929 & 0,000 & 6.741 & 7,751 \\
\hline & Candra. 2012 & 1,249 & 0.152 & 0,023 & 0.950 & 1,548 & 8.190 & 0,000 & 2,74 & 7.441 \\
\hline & Znuet al 2010 & 0,436 & 0,127 & 0.016 & 0.187 & 0,685 & 3.430 & 0,001 & $3,94 \mid$ & 7.601 \\
\hline & Hang ef $\mathrm{Km} 2002^{\circ}$ & 0,563 & 0099 & 0,010 & 0,369 & 0,757 & 5,683 & 0,000 & 6.49 I & $7,74 !$ \\
\hline & Hong et $\mathrm{Km} 2002$ & $-0,497$ & 0,099 & 0,010 & -0.691 & $-0,303$ & -5.023 & 0,000 & 6.491 & 7.741 \\
\hline & Sedera et Cable 2010 & 1.256 & 0,057 & 0,003 & 1,144 & 1,368 & 22010 & 0,000 & $19,53 \mathbf{~}$ & $790 i$ \\
\hline & Eradford et Florin $2003^{\circ}$ & 0,314 & 0,144 & 0,021 & 0031 & 0,597 & 2176 & $0, \infty, 0$ & 3,06 & 7,491 \\
\hline & Bradtord et Flonn. 2003 & 0,519 & 0.144 & 0,021 & 0.236 & 0,802 & 3,086 & 0,000 & 3,051 & $7,49 \mathbf{I}$ \\
\hline & Chou ef Chang 2008 & 0.227 & 0.078 & 0,006 & 0,073 & 0,380 & 2.896 & 0,004 & $10,37 \mathbf{I}$ & 7.831 \\
\hline & Grant et al 2013 & 0,090 & 0,092 & 0,000 & -0.009 & 0,270 & 0,994 & 0,325 & $7.57 \mathbf{i}$ & 7.781 \\
\hline Flaed & & 0.760 & 0.025 & 0,001 & 0.711 & 0,810 & 30.145 & 0,000 & & \\
\hline Rendom & & 0,626 & 0.159 & 0,025 & 0,314 & 0,988 & 3934 & 0,000 & & \\
\hline
\end{tabular}

Funnel Plot of Standard Error by Fisher's Z

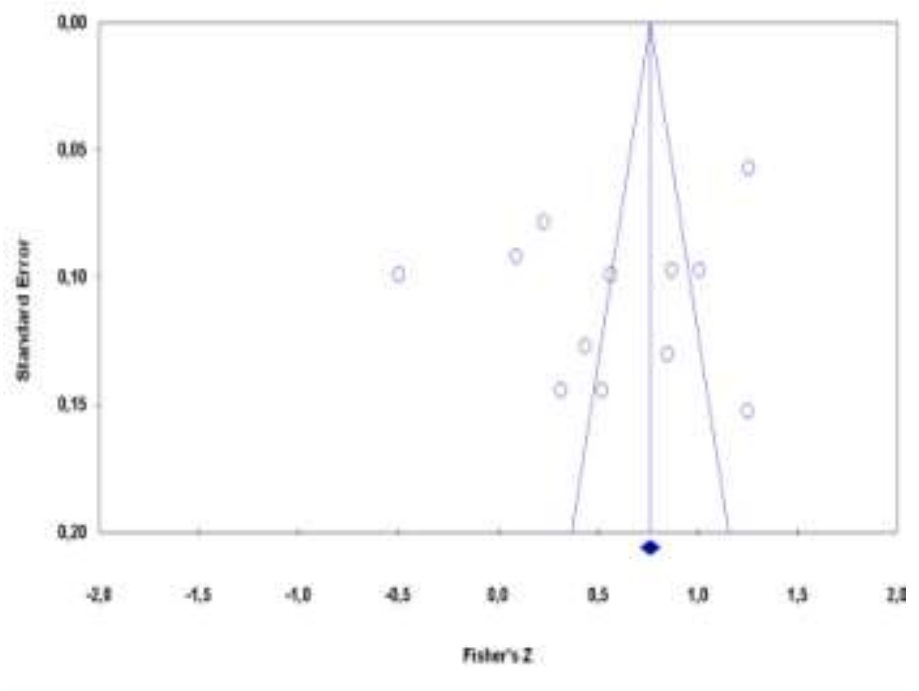

Classic failsafe $\mathrm{N}$

2.vatuo ic aserved stide

25,46348

Piatue for acoerved atide

000000

006000

Tas

200000

1.80006

1200000

Nunber od observed stuses

218200000

\section{Orwin's failsafe $N$}

Fahers Zn observed sudes

0.760030

Chenon bor a rival fivoro $z$

0,00000

Noen fihers $z$ in minsing stades

2,00000

Qturon nuat hal tetinem otwer value 
Top Management Support

\begin{tabular}{|c|c|c|c|c|c|c|c|c|c|c|c|c|}
\hline \multirow[t]{2}{*}{ Study name } & \multicolumn{7}{|c|}{ Statistics for each study } & \multicolumn{5}{|c|}{ Fisher's $\mathrm{Z}$ and $95 \% \mathrm{Cl}$} \\
\hline & $\begin{array}{c}\text { Fisher's } \\
z\end{array}$ & $\begin{array}{l}\text { Standard } \\
\text { error }\end{array}$ & Variance & $\begin{array}{l}\text { Lower } \\
\text { limit }\end{array}$ & $\begin{array}{c}\text { Upper } \\
\text { limit }\end{array}$ & z-Value & p-Value & & & & & \\
\hline Zhu et al. 2010 & 0,743 & 0,127 & 0,016 & 0,494 & 0,992 & 5,851 & 0,000 & & & & & 1 \\
\hline Ehie et Madsen. 2005 & 0,858 & 0,174 & 0.030 & 0,516 & 1,199 & 4,926 & 0,000 & & & & & \\
\hline Bradford et Florin. 2003 & 0,279 & 0,144 & 0,021 & $-0,004$ & 0,562 & 1,933 & 0,053 & & & & & \\
\hline Bradford et Florin. 2003 & 0,511 & 0,144 & 0,021 & 0,228 & 0,794 & 3,543 & 0,000 & & & & & \\
\hline Wang et al. 2008 & 0,497 & 0,107 & 0,011 & 0,287 & 0,707 & 4,639 & 0,000 & & & & & \\
\hline Scott et Walczak. 2009 & 0,332 & 0,066 & 0,004 & 0,203 & 0,461 & 5,041 & 0,000 & & & & & \\
\hline Kwahk et Lee. 2008 & 0,510 & 0,061 & 0,004 & 0,391 & 0,629 & 8,381 & 0,000 & & & & & \\
\hline Bernroider et al. 2014 & 1,071 & 0,070 & 0,005 & 0,935 & 1,208 & 15,378 & 0,000 & & & & & \\
\hline Chung et at. 2008 & 0,563 & 0,060 & 0,004 & 0,445 & 0,680 & 9,383 & 0,000 & & & & & \\
\hline \multirow[t]{4}{*}{ Shih et Huang. 2009} & 0,618 & 0,079 & 0,006 & 0,464 & 0,772 & 7,871 & 0,000 & & & & & \\
\hline & 0,595 & 0,026 & 0,001 & 0,543 & 0,646 & 22,444 & 0,000 & & & & & \\
\hline & & & & & & & & \multirow[t]{2}{*}{$-2,00$} & $-1,00$ & 0,00 & 1,00 & 2,00 \\
\hline & & & & & & & & & Favours A & & Favours B & \\
\hline
\end{tabular}

\begin{tabular}{|c|c|c|c|c|c|c|c|c|c|c|}
\hline \multirow[t]{2}{*}{ Model } & \multirow[t]{2}{*}{ Shody name } & \multicolumn{7}{|c|}{ Statistics for each stuoy } & \multirow{2}{*}{$\begin{array}{l}\text { Weight (Fond) } \\
\text { Reiative wesst }\end{array}$} & \multirow{2}{*}{$\begin{array}{l}\text { Weight (Rondom) } \\
\text { Relative weidnt }\end{array}$} \\
\hline & & Fisher's Z & $\begin{array}{l}\text { Standard } \\
\text { extor }\end{array}$ & Veriance & Loves init & Upper imt & 2-vesue & D-Vadue & & \\
\hline & Zhu et al. 2010 & 0.743 & 0,127 & 0,016 & 0,494 & 0.992 & 5.851 & 0,000 & 4.351 & 9.281 \\
\hline & Ene es Madsen 2005 & 0.858 & 0.174 & 0,030 & 0,516 & 1.199 & 4,926 & 0,000 & 2321 & $7,72 \mathbf{i}$ \\
\hline & Eradioxd et Fiom. 2003 & 0.279 & 0,144 & 0,021 & $=0,004$ & 0,562 & 1,933 & 0.053 & 3371 & $8.70 \mathbf{I}$ \\
\hline & Eradford et Forn, 2003 & 0,511 & 0,144 & 0,021 & 0.228 & 0,794 & 3,563 & 0,000 & 3,371 & 8,701 \\
\hline & Wang et a. 2008 & 0.497 & 0.107 & 0,011 & 0.287 & 0,707 & 4.639 & 0,000 & 6.111 & $9.94 \mathbf{I}$ \\
\hline & Scott et Waiczak 2009 & 0.332 & 0,068 & 0,004 & 0.203 & 0.461 & 5.041 & 0,000 & 16.210 & $11,17 \mathbf{I}$ \\
\hline & Kwohket Len 2008 & 0.510 & 0,061 & 0,004 & 0.391 & 0629 & 8.381 & 0,000 & $1895 \overline{\mathbf{0}}$ & 11.29 \\
\hline & Bemroider ef al 2014 & 1.071 & 0,070 & 0,005 & 0.935 & 1.208 & 15,378 & 0,000 & $1446 \overline{\mathrm{J}}$ & 11.07 \\
\hline & Ching et al 2008 & 0,563 & 0,060 & 0,004 & 0.445 & 0.680 & 9,383 & 0,000 & 19.51 且 & 11,31 I \\
\hline & Shth et Huang 2000 & 0.618 & 0.079 & 0,006 & 0.464 & 0.772 & 7,871 & 0,000 & $11,37 \mathbf{I}$ & 10.82 \\
\hline Fined & & 0.595 & 0,028 & 0,001 & 0.543 & 0.648 & 22.444 & 0,000 & & \\
\hline Random & & 0,697 & 0.081 & 0,006 & 0,439 & 0.755 & 7,414 & 0,000 & & \\
\hline
\end{tabular}




\section{Funnel Plot of Standard Error by Fisher's Z}

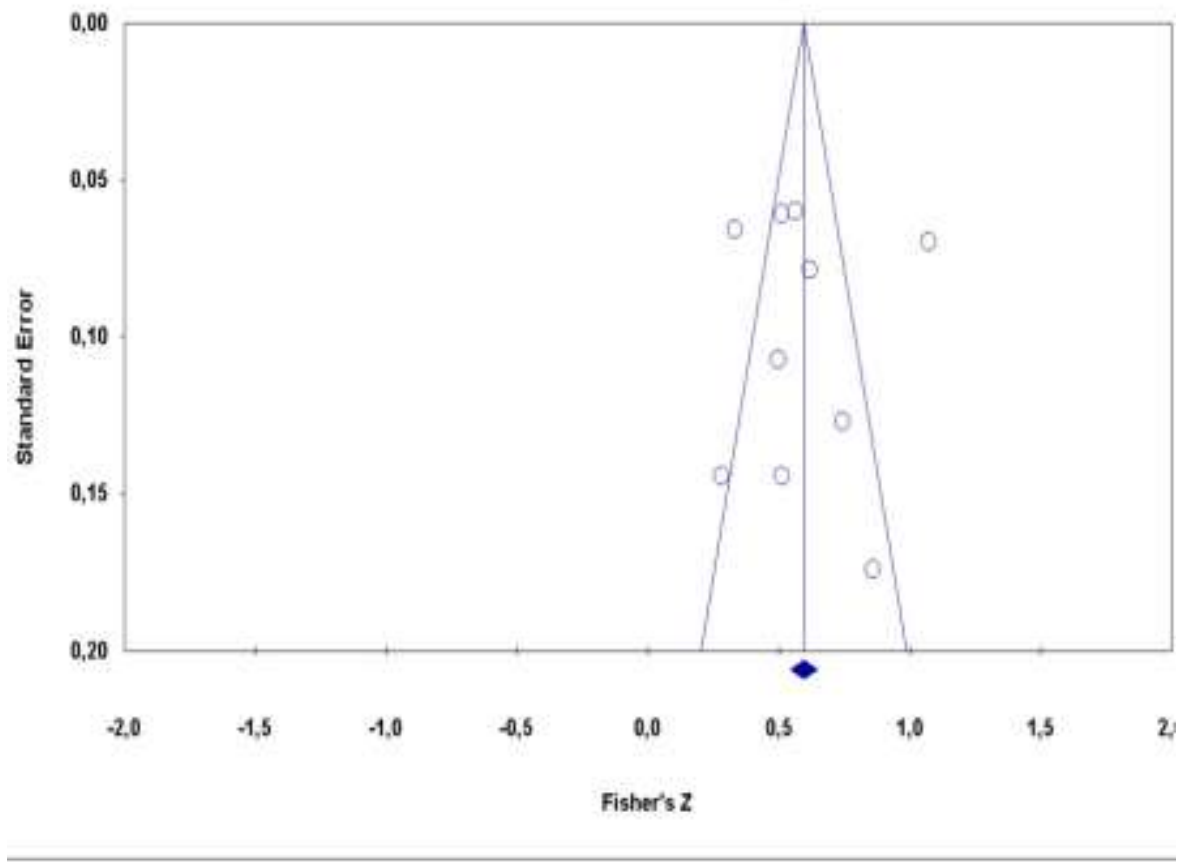

\section{Classic fail-safe $\mathrm{N}$}

Z-value for observed studies

21.16985

P-value for observed studies

0,00000

Alpha

0,05000

Tais

2,00000

$Z$ for alpha

1,95996

Number $\alpha$ observed studies

10,00000

Number of missing studies that would bring p-value to > alpha

1157,00000

\section{Orwin's fail-safe N}

Fisher's $Z$ in observed studies

0,59455

Criterion for a 'trival' fisher's z

0,00000

Mean fisher's $z$ in missing studies

0,00000 


\section{Vendor Consultant Quality}

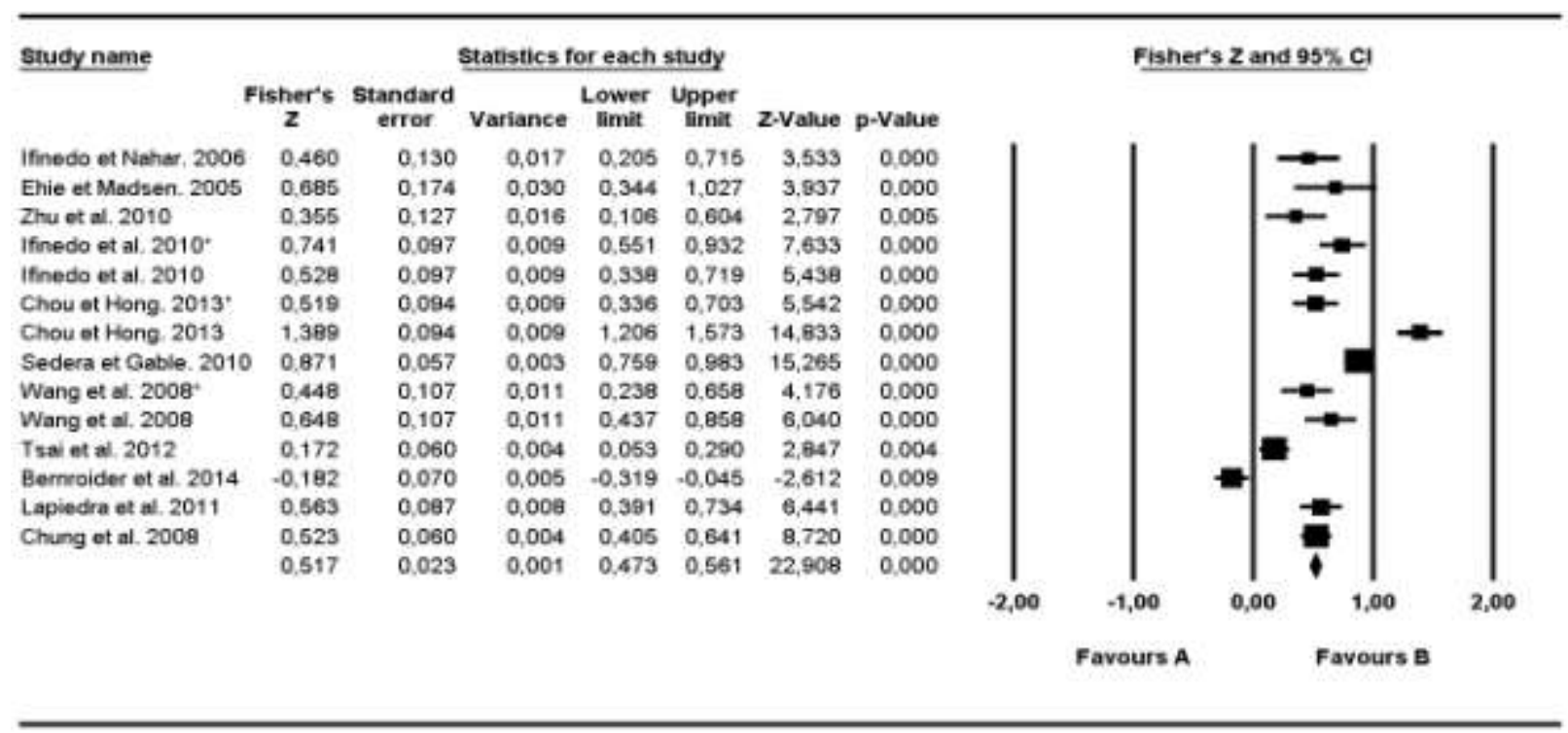

\begin{tabular}{|c|c|c|c|c|c|c|c|c|c|c|}
\hline \multirow[t]{2}{*}{ Nodel } & \multirow[t]{2}{*}{ Study name } & \multicolumn{7}{|c|}{ Statistes for each study } & \multirow{2}{*}{$\begin{array}{l}\text { Weight (Fined) } \\
\text { Reiative weigh }\end{array}$} & \multirow{2}{*}{$\begin{array}{l}\text { Weight iRandom } \\
\text { Relative weoht }\end{array}$} \\
\hline & & Fisher's 2 & $\begin{array}{l}\text { Standord } \\
\text { errof }\end{array}$ & Varance & Lower inst & Usoer int & 2-vace & D-value & & \\
\hline & Ifnedo es Nahar. 2006 & 0,460 & 0,130 & 0.017 & 0.205 & 0,715 & 3,530 & 0,000 & $3, \infty 01$ & 6841 \\
\hline & Ehie ef Madaen 2005 & 0.685 & 0.174 & 0,030 & 0.344 & 1,027 & 3.937 & 0,000 & 1,65 & 6,321 \\
\hline & Znuet at 2010 & 0,355 & 0.127 & 0016 & 0.706 & 0.604 & 2797 & 0.005 & 3,161 & 6.881 \\
\hline & ifnedo et al. $2010^{\circ}$ & 0,741 & 0.097 & 0,000 & 0,661 & 0.032 & 7,633 & 0,000 & 5,391 & $7,17 \mathbf{I}$ \\
\hline & ifnedo et al 2010 & 0.528 & 0.097 & 0009 & 0.338 & 0.719 & 5,438 & 0,000 & $5,39 i$ & $7.17 \mathbf{i}$ \\
\hline & Chou et Hong $2013^{\circ}$ & 0.519 & 0,084 & 0.009 & 0.396 & 0,703 & 5,542 & 0.000 & 5,801 & $7.21 \mathbf{i}$ \\
\hline & Chou et Hong 2013 & 1,389 & 0,094 & 0.009 & 1.208 & 1,573 & 14.833 & 0,000 & 5.801 & $7.21 \mathbf{i}$ \\
\hline & Sedere et Gebie. 2010 & 0.871 & 0,067 & 0003 & 0.799 & 0,983 & 15,266 & 0,000 & $15,62 \mathbf{7}$ & $7.47 \mathbf{I}$ \\
\hline & Wanget a $2000^{\circ}$ & 0,448 & 0,107 & 0.011 & 0.238 & 0.658 & 4,176 & 0.000 & 4.431 & $7.000 \mathbf{i}$ \\
\hline & Winget a 2006 & 0,648 & 0,107 & 0.011 & 0,437 & 0,258 & 6.040 & 0,000 & 4,431 & $7.08 \mathbf{i}$ \\
\hline & Tsai a a. 2012 & 0,172 & 0.060 & 0,004 & 0,063 & 0.290 & 2,847 & 0,004 & $13,99 \mathbf{n}$ & $7,46 i$ \\
\hline & Bemroider et at 2014 & $-0,182$ & 0,070 & 0005 & $-0,319$ & $-0,045$ & $-2,612$ & 0,009 & $10,46 \mathbf{I}$ & 7.401 \\
\hline & Lapiedra ef al. 2011 & 0,563 & 0,087 & 0,008 & 0,391 & 0.734 & 6,441 & 0,000 & 5,571 & 7.261 \\
\hline & Chung et al 2008 & 0,523 & 0,060 & 0,004 & 0.405 & 0.641 & 8.720 & 0.000 & 14.15 & $7.46 \mathbf{I}$ \\
\hline Fand & & 0,517 & 0,023 & 0,001 & 0.473 & 0,561 & 22.908 & 0,000 & & \\
\hline Ransom & & 0,550 & 0.106 & 0.011 & 0.344 & 0.756 & 5.231 & 0,000 & & \\
\hline
\end{tabular}


Funnel Plot of Standard Error by Fisher's Z

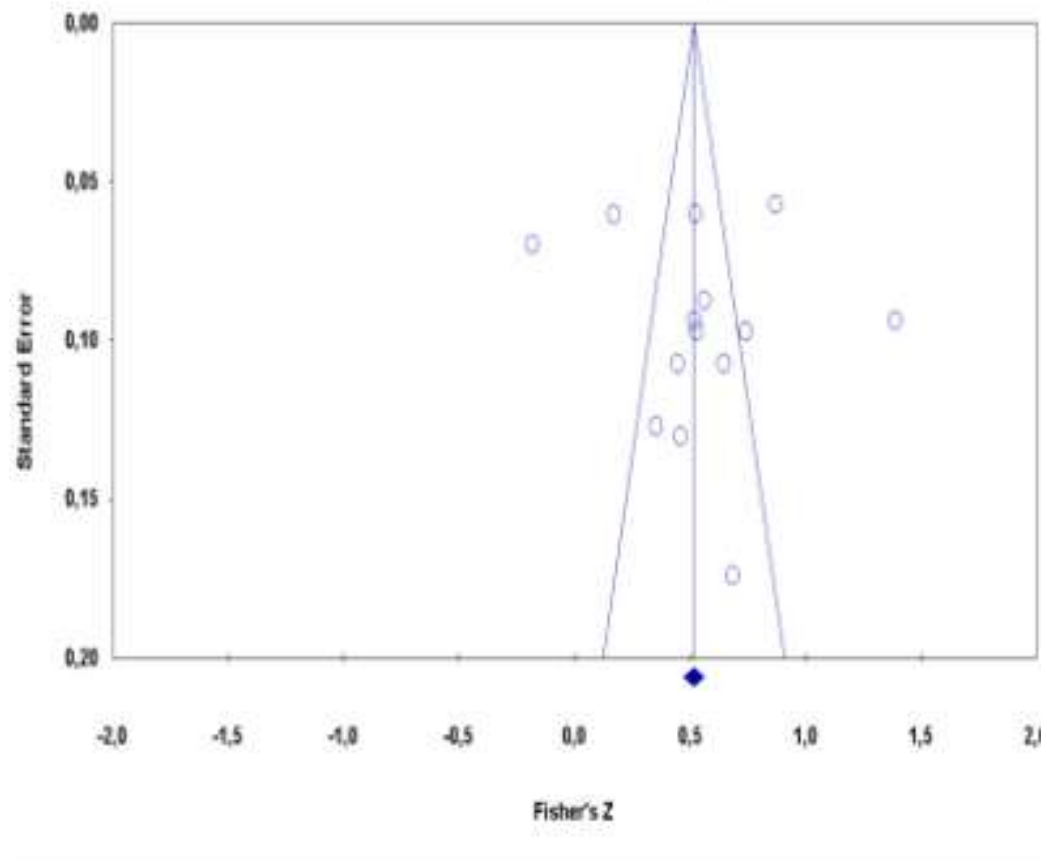

\section{Classic fail-safe $\mathrm{N}$}

$Z$-value for coserved studies

22,60752

P-value for coserved studies

0.00000

Alpha

0,05000

Tals

2,00000

$Z$ for alphe

1,95996

Number of observed studes

14,00000

Number of missing studies that would bring p-value to > apha

1849.00000

\section{Orwin's fail-safe $\mathrm{N}$}

Fisher's $Z$ in observed studies

0,51678

Criterion for a trival fisher's z

0,00000

Mean fisher's $z$ in missing studies

0.00000 


\section{Training and Education}

\begin{tabular}{|c|c|c|c|c|c|c|c|c|c|c|c|}
\hline \multirow[t]{2}{*}{ Study name } & \multicolumn{7}{|c|}{ statistics for each study } & \multicolumn{4}{|c|}{ Fisher's 2 and $95 \% \mathrm{CI}$} \\
\hline & $\begin{array}{c}\text { Fisher's } \\
\text { z }\end{array}$ & $\begin{array}{l}\text { Standard } \\
\text { error }\end{array}$ & Variance & $\begin{array}{l}\text { Lower } \\
\text { limit }\end{array}$ & $\begin{array}{c}\text { Upper } \\
\text { ilmit }\end{array}$ & z-Value & p-Value & & & & \\
\hline Ram ot ab. 2013 (a) & 0,422 & 0,068 & 0,005 & 0,288 & 0,556 & 6,180 & 0,000 & & & & \\
\hline Bradford et Florin. $2003^{+}$ & 0,256 & 0,144 & 0,021 & $-0,027$ & 0,538 & 1,770 & 0,077 & & & & \\
\hline Bradford et Florin. 2003 & 0.656 & 0,144 & 0,021 & 0,372 & 0,938 & $4,53 \theta$ & 0,000 & & & & \\
\hline Ram ot al. 2013 (b) & 0,472 & 0,070 & 0,005 & 0,336 & 0,609 & 6,778 & 0,000 & & & & \\
\hline Choi et al 2007 & 0,600 & 0,067 & 0,005 & 0,468 & 0,732 & 8,898 & 0.000 & & & & \\
\hline \multirow[t]{4}{*}{ Bernroider et al 2014} & 0.224 & 0,070 & 0,005 & 0,087 & 0,360 & 3,210 & 0,001 & & & & \\
\hline & 0,435 & 0,033 & 0,001 & 0,371 & 0.499 & 13,340 & 0,000 & & & & \\
\hline & & & & & & & & $-2,00$ & $-1,00$ & 0,00 & 2,00 \\
\hline & & & & & & & & & Favours A & Favours & \\
\hline
\end{tabular}

\begin{tabular}{|c|c|c|c|c|c|c|c|c|c|c|}
\hline \multirow[t]{2}{*}{ Model } & \multirow[t]{2}{*}{ Sudyname } & \multicolumn{7}{|c|}{ Statsics for each study } & \multirow{2}{*}{$\begin{array}{l}\text { Weight (Fxod) } \\
\text { Relatilie meght }\end{array}$} & \multirow{2}{*}{$\begin{array}{l}\text { Weight (Random) } \\
\text { Relatve weight }\end{array}$} \\
\hline & & Fisher's Z & $\begin{array}{l}\text { Standard } \\
\text { error }\end{array}$ & Variance & Lower init & Upper imt & Z-Vabe & p-lalue & & \\
\hline & Rem et al. 2013 (a) & 0,422 & 0,068 & 0,005 & 0,288 & 0,556 & 6,180 & 0,000 & 22,72 & 19,29 \\
\hline & Bratlordet Florn $2003^{\circ}$ & 0.265 & 0,144 & 0021 & $-0,027$ & 0,538 & 1,770 & 0,077 & 5,101 & $11,51 \mid$ \\
\hline & Bratflordet Florn 2003 & $0, E E 5$ & 0,144 & 0,021 & 0,372 & 0,938 & 4,538 & 0,000 & 5,101 & 11,51 | \\
\hline & Ram et a. $2013|b\rangle$ & 0,472 & 0,070 & 0,005 & 0,336 & 0,609 & 6,778 & 0,000 & 21,87 & 19,15 \\
\hline & Oha et al 2007 & 0,600 & 0,067 & 0,005 & 0,468 & 0,732 & 8,898 & 0,000 & 23,25 므 & 19,39 \\
\hline & Bemroder et al 2014 & 0,224 & 0,070 & 00055 & 0,067 & 0,360 & 3,210 & 0,001 & 21,87 & 19,15 \\
\hline Fved & & 0,435 & 0,033 & 0,001 & 0,371 & 0,499 & 13,340 & 0,000 & & \\
\hline Random & & 0,436 & 0,068 & 0005 & 0,303 & 0,569 & 6,417 & 0,000 & & \\
\hline
\end{tabular}




\section{Funnel Plot of Standard Error by Fisher's Z}

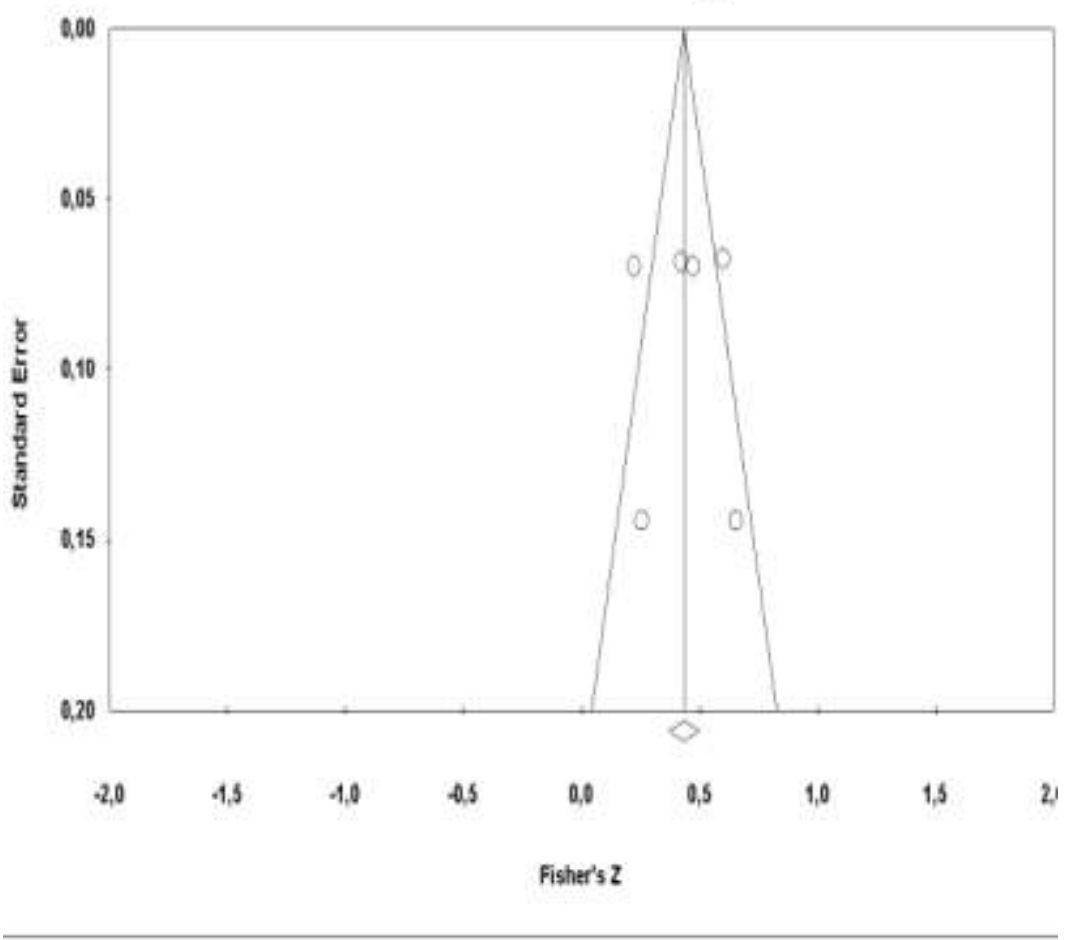

\section{Classic fail-safe $\mathrm{N}$}

Z-value for observed studies

12,80820

P-value for observed studies

0,00000

Apha

0,05000

Tals

2,00000

Z for alpha

1,95996

Number of observed studies

6,00000

Number of missing studies that would bring p-value to $>$ alpha

251,00000

\section{Orwin's fail-safe $\mathrm{N}$}

Fisher's $Z$ in observed studes

0,43465

Criterion for a trivial fisher's z

0,00000

Mean fisher's $z$ in missing studies

0,00000 


\section{Business Process Reengineering}

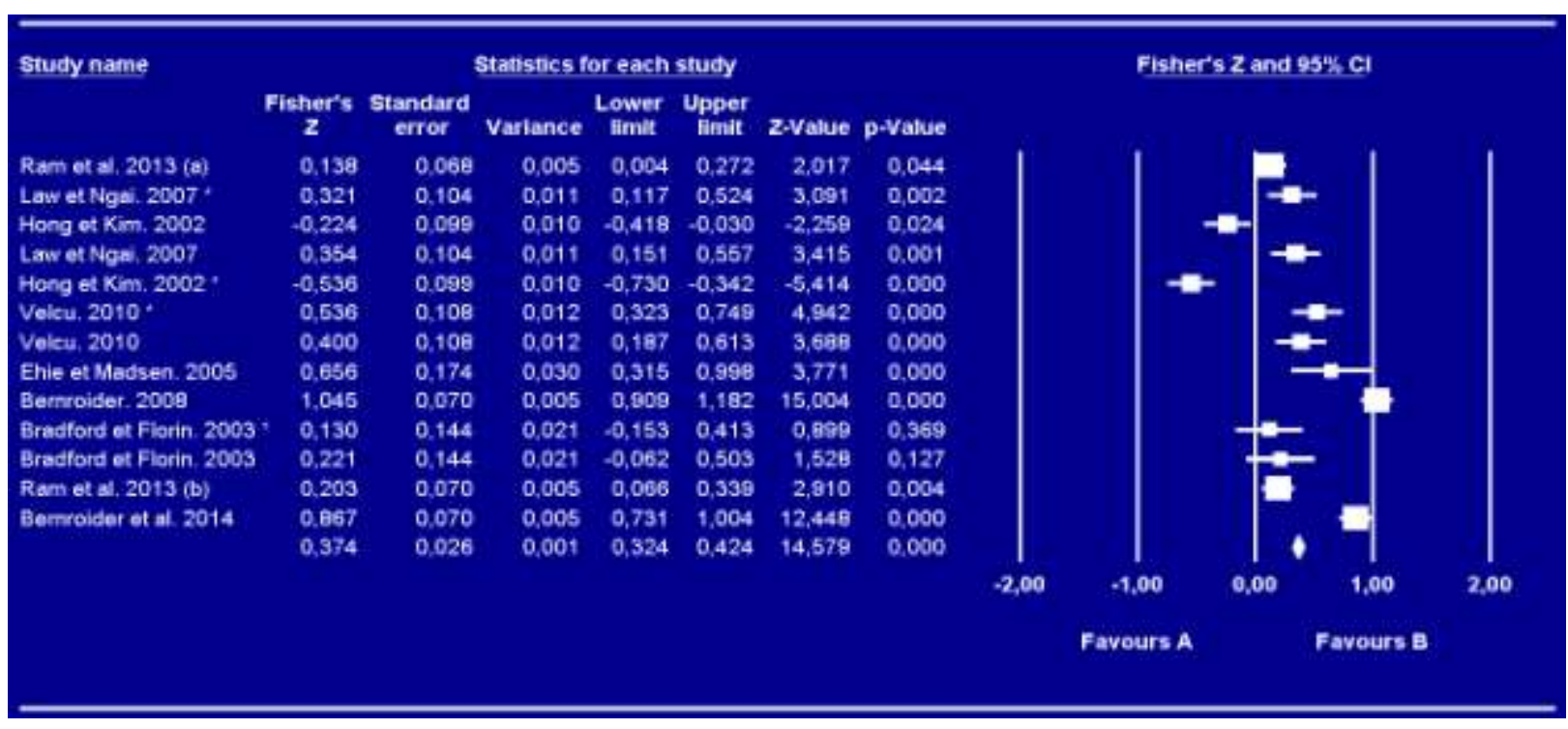

\begin{tabular}{|c|c|c|c|c|c|c|c|c|c|c|}
\hline \multirow[t]{2}{*}{ Model } & \multirow[t]{2}{*}{ Sudy nane } & \multicolumn{7}{|c|}{ Statistics for eoch study } & \multirow{2}{*}{$\begin{array}{l}\text { Weight ( Fixed) } \\
\text { Relabue weight }\end{array}$} & \multirow{2}{*}{$\begin{array}{l}\text { Weighe \& Ransom, } \\
\text { Reiatve weight }\end{array}$} \\
\hline & & Fishers $z$ & $\begin{array}{l}\text { Standard } \\
\text { error }\end{array}$ & Variance & Lover imit: & Upper imt & 2-Vatue & D. Shive & & \\
\hline & Ram ef a. 2013 (a) & 0,138 & 0,068 & 0,005 & 0,004 & 0.272 & 2,017 & 0,044 & $14,07 \mathbf{7}$ & 7,951 \\
\hline & Law ef Nga, 2007 " & 0,321 & 0,104 & 0011 & 0,117 & 0,524 & 3,091 & 0,002 & 6.111 & $7,73 \mathbf{I}$ \\
\hline & Hang ef Kam $290 \mathrm{Ce}$ & $-0,224$ & 0,099 & 0.010 & $=0,418$ & $-0,030$ & -2.259 & 0,024 & 6.711 & 7,761 \\
\hline & Lawet Nax. 2007 & 0,354 & 0,104 & 0011 & $0.15 \%$ & 0.557 & 3.415 & 0,001 & 6.111 & 7.731 \\
\hline & Hong et Kam $2002^{\circ}$ & $-0,536$ & 0.099 & 0.010 & -0.730 & -0.342 & -5.414 & 0,000 & 6.711 & $7,76 !$ \\
\hline & Vecu $2010^{\circ}$ & 0,536 & 0,108 & 0,012 & 0.323 & 0.749 & 4.942 & 0,000 & 5.591 & 7.091 \\
\hline & Vatcu 2010 & 0,400 & 0,108 & 0,012 & 0,187 & 0.613 & 3,688 & 0,000 & 5,591 & 7,091 \\
\hline & Bie et Madsen. 2005 & 0,658 & 0.174 & 0,030 & 0.315 & 0.998 & 3,771 & $0, \infty \infty$ & $2,17 \mid$ & 70051 \\
\hline & Bernroise, 2006 & 1,045 & 0.070 & 0,005 & 0,960 & 1,182 & 15,004 & 0,000 & $13,54]$ & 7.951 \\
\hline & Bradscrd et Fiom. $2003^{\circ}$ & 0,130 & 0,144 & 0.021 & $-0,163$ & 0.413 & 0,899 & 0,369 & 3,161 & $7,38 \mathbf{i}$ \\
\hline & Bradiord et Form. 2003 & 0,221 & 0,144 & 0.021 & -0.062 & 0,503 & 1,528 & 0.127 & 3,161 & $7,38 \mathbf{I}$ \\
\hline & Ram et a 2013 (b) & 0.203 & 0,070 & 0,006 & 0,006 & 0,339 & 2,910 & 0,004 & $13,54 \mathbf{~}$ & $795 \mathbf{i}$ \\
\hline & Bernroider et al 2014 & 0,867 & 0.070 & 0,006 & 0.731 & 1.004 & 12.448 & 0,000 & $13,54 \overline{\mathbf{Z}}$ & $795 \mathbf{I}$ \\
\hline Foend & & 0,374 & 0,008 & 0,001 & 0324 & 0.424 & 14,579 & 0,000 & & \\
\hline Random & & 0,317 & 0.129 & 0.017 & 0.064 & 0.589 & 2,458 & 0.014 & & \\
\hline
\end{tabular}




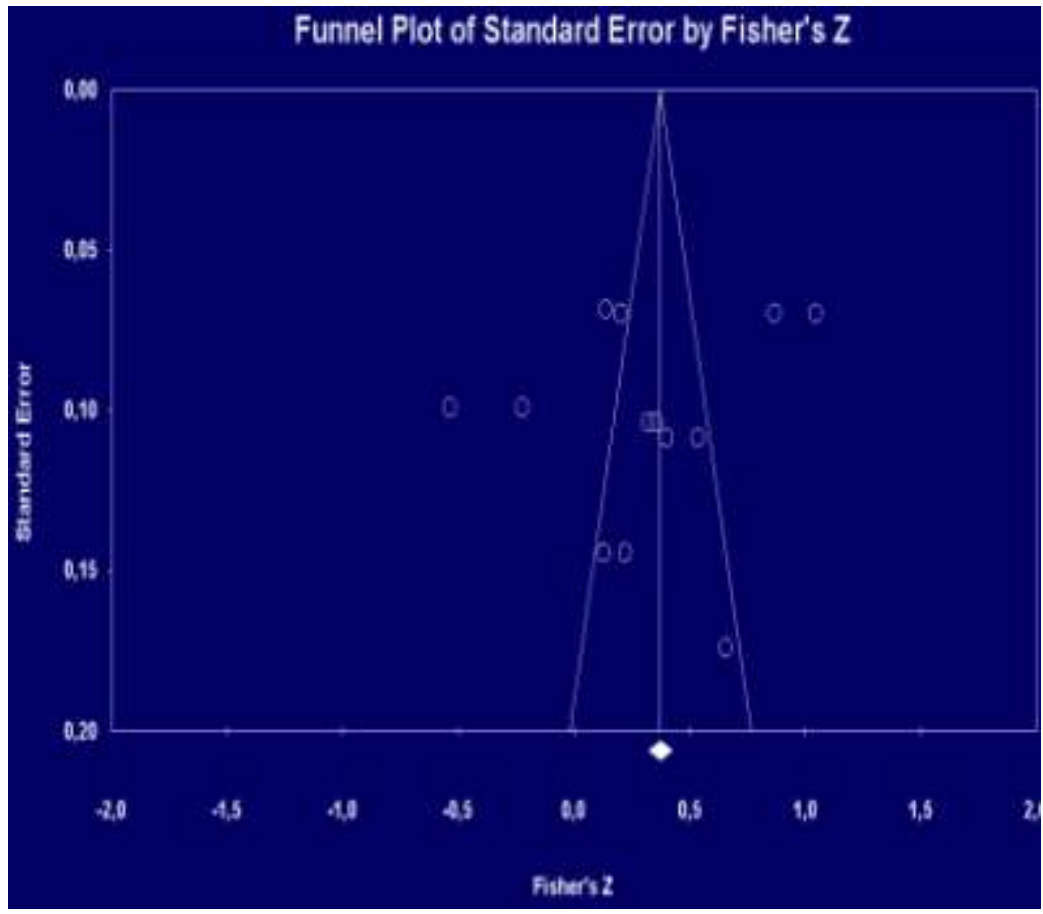

\section{Classic fail-safe $\mathrm{N}$}

$\begin{array}{lr}\text { Z-value for observed studies } & 12,76917 \\ \text { P-value for observed studies } & 0,00000 \\ \text { Alpha } & 0,05000 \\ \text { Tais } & 2,00000 \\ Z \text { for alpha } & 1,95996 \\ \text { Number of coserved studies } & 13,00000 \\ \text { Number of missing studies that would bring p-value to > alpha } & 539,00000\end{array}$

\section{Orwin's fail-safe $\mathrm{N}$}

Fisher's Z in observed studes

0,37381

Criterion for a trival fisher's z

0,00000

Mean fisher's z in missing studies

0,00000 


\section{Project Management}

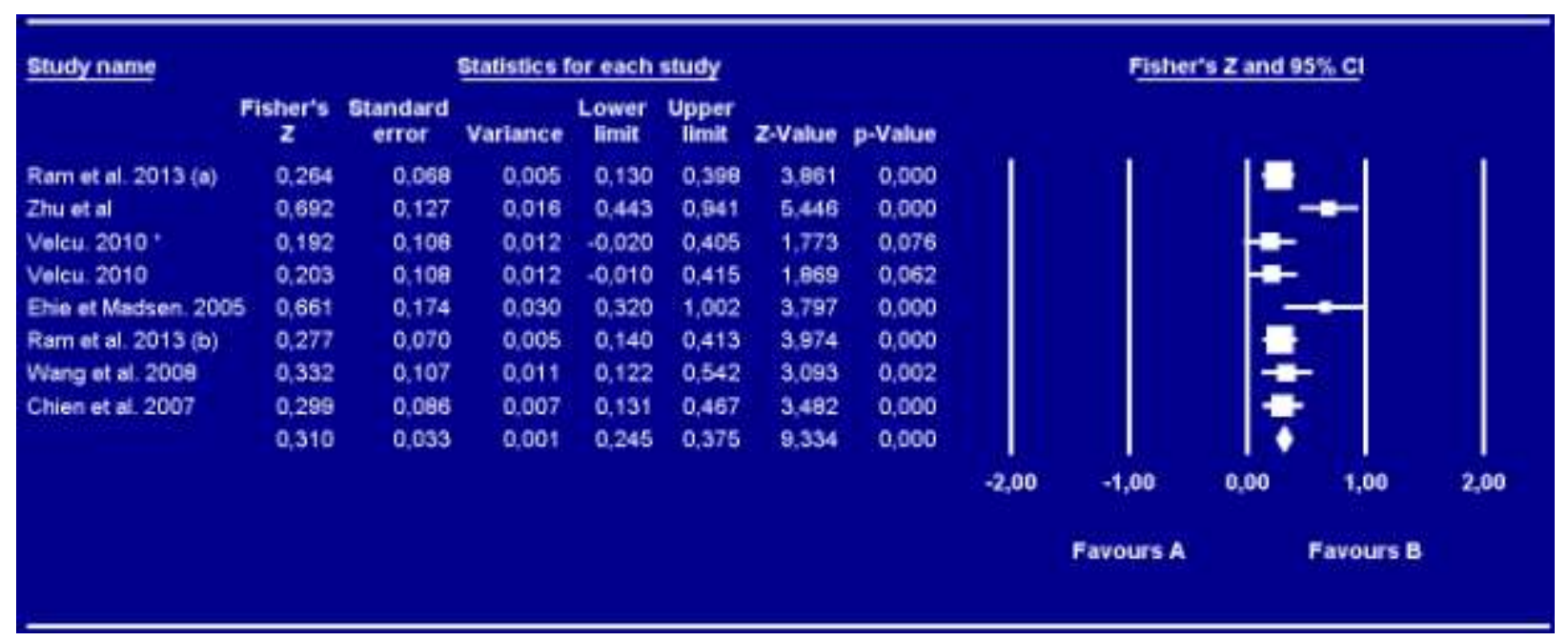

\begin{tabular}{|c|c|c|c|c|c|c|c|c|c|c|}
\hline \multirow[t]{2}{*}{ Model } & \multirow[t]{2}{*}{ Studyname } & \multicolumn{7}{|c|}{ Statistics for each study } & \multirow{2}{*}{$\begin{array}{l}\text { Weight (Fied) } \\
\text { Relative weight }\end{array}$} & \multirow{2}{*}{$\begin{array}{l}\text { Weight (Rendom) } \\
\text { Relative weight }\end{array}$} \\
\hline & & Fisher's 2 & $\begin{array}{l}\text { Standard } \\
\text { enror }\end{array}$ & Veriance & Lover imt & Uoper imit & 2-Vave & D-vave & & \\
\hline & Ram et al $2013(a)$ & 0.264 & 0,068 & 0,005 & 0.130 & 0,398 & 3861 & 0,000 & 23,57 & 1885 \\
\hline & Zhu et al & 0.692 & 0.127 & 0.016 & 0.443 & 0,941 & 5,446 & 0,000 & 6.831 & 9.941 \\
\hline & Velcu $2010^{\circ}$ & 0,192 & 0,108 & 0012 & $-0,020$ & 0,406 & 1.773 & 0,076 & 9361 & 11,781 \\
\hline & Vercu. 2010 & 0203 & 0,108 & 0.012 & -0010 & 0,415 & 1.869 & 0,062 & 9,361 & 11.781 \\
\hline & Eie et Madsen. 2005 & 0,661 & 0,174 & 0,030 & 0,320 & 1,002 & 3,797 & 0,000 & 3,631 & 6.591 \\
\hline & Ram et al $2013(\mathrm{~b})$ & 0.277 & 0,070 & 0,005 & 0.140 & 0,413 & 3974 & 0,000 & 22,69 & 16.68 \\
\hline & Wanget a 2006 & 0.332 & 0,107 & 0.011 & 0.122 & 0,542 & 3098 & 0,002 & $9,58 \mathbf{I}$ & 11,911 \\
\hline & Orien el al 2007 & 0299 & 0,006 & 0,007 & 0,131 & 0.467 & 3482 & 0,000 & $14,98]$ & 14.49 \\
\hline Fuxed & & 0,310 & 0,063 & 0001 & 0245 & 0.375 & 9334 & 0,000 & & \\
\hline Random & & 0,332 & 0,063 & 0,003 & 0.229 & 0.436 & 6.306 & 0,000 & & \\
\hline
\end{tabular}




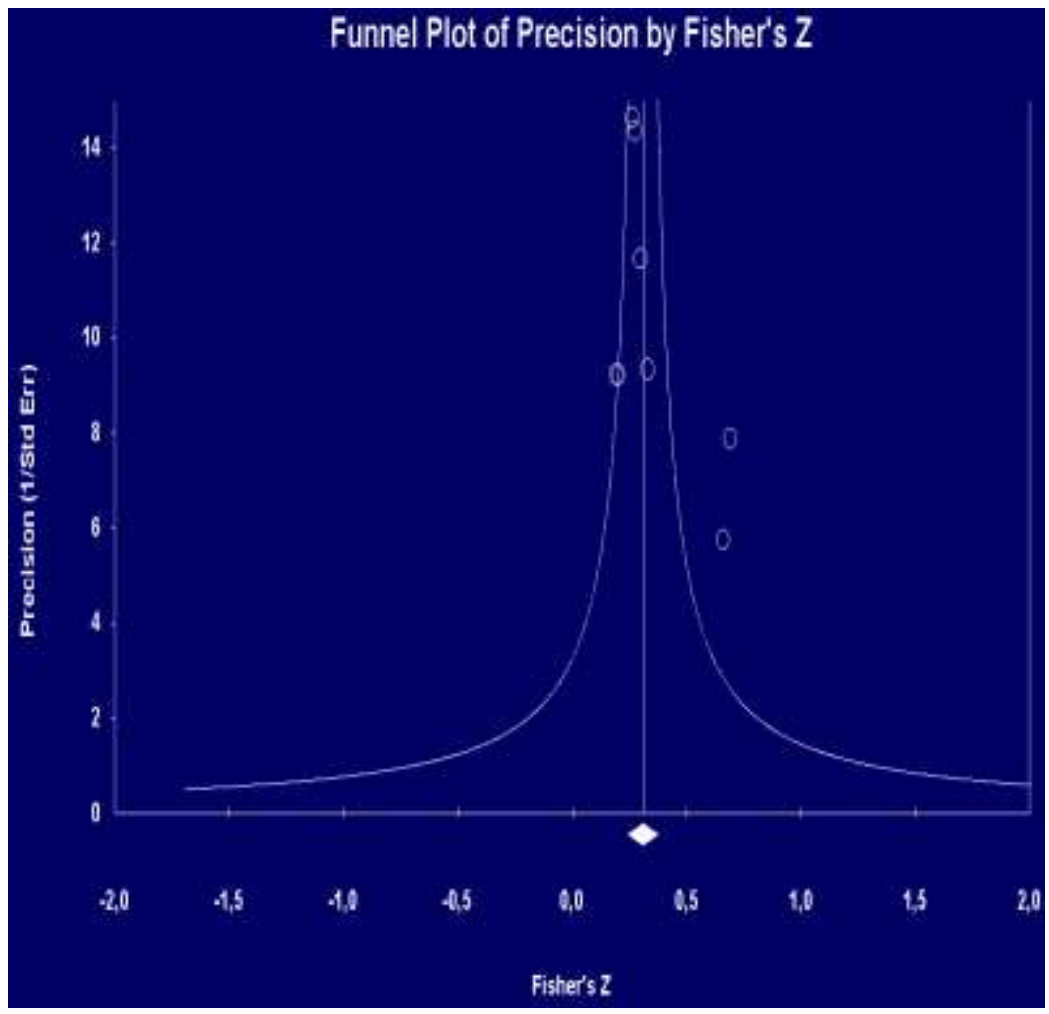

\section{Classic fail-safe $\mathrm{N}$}

$\begin{array}{lr}\text { Z-value for observed studies } & 9.65034 \\ \text { P-value for observed studies } & 0,00000 \\ \text { Alpha } & 0.05000 \\ \text { Tals } & 200000 \\ \text { Z for alpha } & 1.95096 \\ \text { Number of coserved studies } & 8.00000 \\ \text { Number of missing studies that would bring p-value to > alpha } & 186,00000\end{array}$

\section{Orwin's fail-safe $\mathrm{N}$}

Fisher's $Z$ in observed studies

0.30975

Criterion for a 'trival' fisher's z

0,00000

Mean fisher's $z$ in missing studies 


\section{ERP Fit}

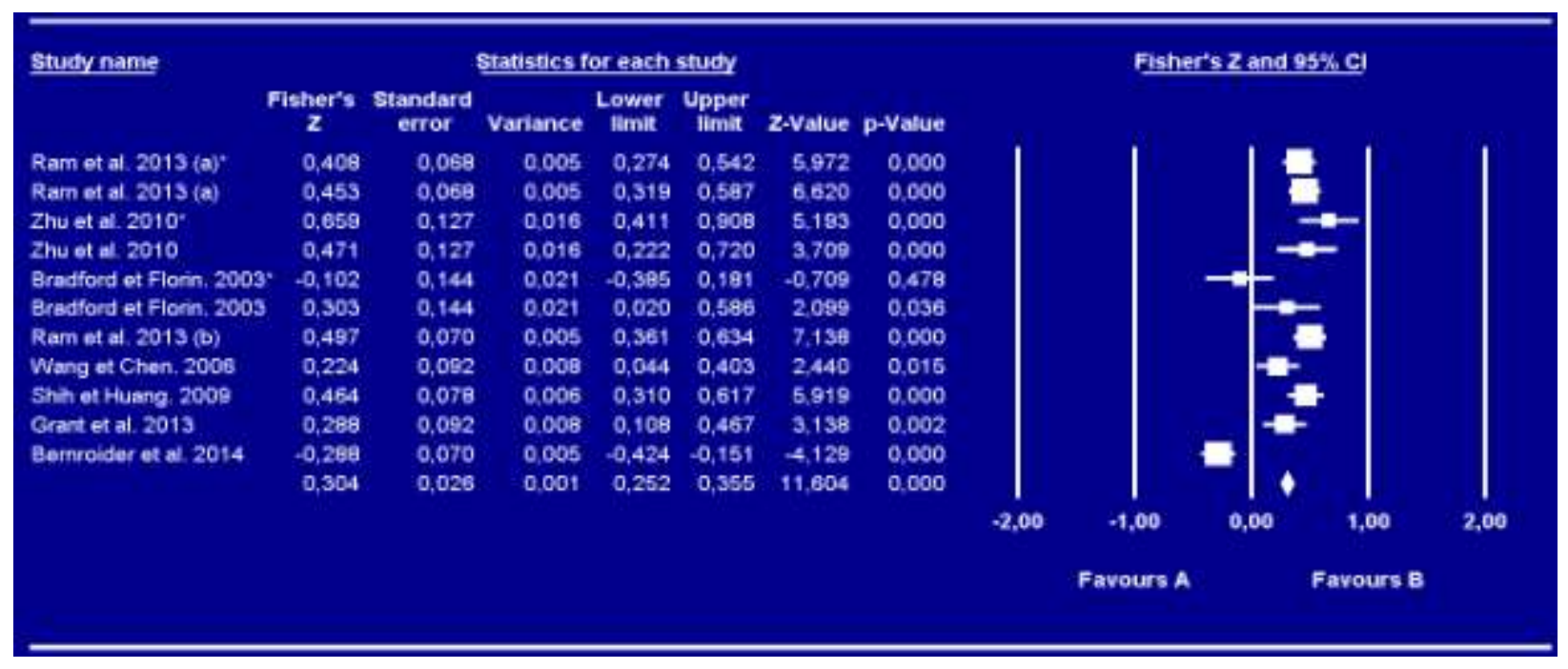

\begin{tabular}{|c|c|c|c|c|c|c|c|c|c|c|}
\hline \multirow[t]{2}{*}{ Model } & \multirow[t]{2}{*}{ Study name } & \multicolumn{7}{|c|}{ Staistes for each study } & \multirow{2}{*}{$\begin{array}{l}\text { Weght (Fbed) } \\
\text { Redasve woicht }\end{array}$} & \multirow{2}{*}{$\begin{array}{l}\text { Weight (Random: } \\
\text { Recasive woight }\end{array}$} \\
\hline & & Fisher's $z$ & $\begin{array}{l}\text { Standard } \\
\text { error }\end{array}$ & Variance & Lower imt & Uboer innt & Z-Vhive & o-valie & & \\
\hline & Rean et w. $2013(a)^{*}$ & 0,406 & 0.068 & 0.005 & 0.274 & 0,542 & 5.972 & 0.000 & $14.65 \mathrm{D}$ & 8701 \\
\hline & Ram et a 2013 (a) & 0,453 & 0.068 & 0,005 & 0.310 & 0.587 & 6.620 & 0,000 & $14,65 \mathbf{0}$ & 9.701 \\
\hline & Zhu et a $2010^{\circ}$ & 0,658 & 0.127 & 0,016 & 0,411 & 0,908 & 5,193 & 0,000 & 4.241 & 8,501 \\
\hline & Zhues at 2010 & 0,47 & 0.127 & 0.016 & 0.222 & 0,720 & 3709 & 0,000 & 4,241 & $850 \mathbf{I}$ \\
\hline & Bradtord at Flom 2000 & -0.102 & 0,144 & 0.021 & -0.385 & Q.4a1 & -0.700 & 0.478 & $3.29 i$ & $800 \mathbf{i}$ \\
\hline & Eradford et Fiorn. 2003 & 0,308 & 0.144 & 0.021 & 0,020 & 0.586 & 2099 & 0,036 & 3291 & $809 \mathbf{I}$ \\
\hline & Ram ot $\alpha 2013$ (b) & 0.497 & 0.070 & 0,005 & $0,36 t$ & 0.634 & 7,138 & 0,000 & 14,10 & 268 \\
\hline & Wanget Ohen 2006 & 0.224 & 0,082 & 0,008 & 0,044 & 0.403 & 2,440 & 0.015 & $8,15 \mathbf{~ I}$ & 927 I \\
\hline & Shin thumg 2000 & 0.464 & 0.078 & 0.006 & 0.310 & 0.617 & 5.919 & 0,000 & $11,16 \mathbf{i}$ & 9.53 \\
\hline & Grant et al 2013 & 0.288 & 0.082 & 0.008 & 0,108 & 0.467 & 3.138 & 0.002 & B, 15 i & $927 \mathbf{i}$ \\
\hline & Eernroder ef a 2014 & .0 .268 & 0.070 & 0.005 & $-0,424$ & $-0.15 t$ & $-4,129$ & 0,000 & 14,10 ] & 9681 \\
\hline Faed & & 0.304 & 0.026 & 0.001 & 0.252 & 0.356 & 11.604 & 0.000 & & \\
\hline Random & & 0.308 & 0.099 & 0.008 & 0.134 & 0.482 & 3.483 & 0.001 & & \\
\hline
\end{tabular}




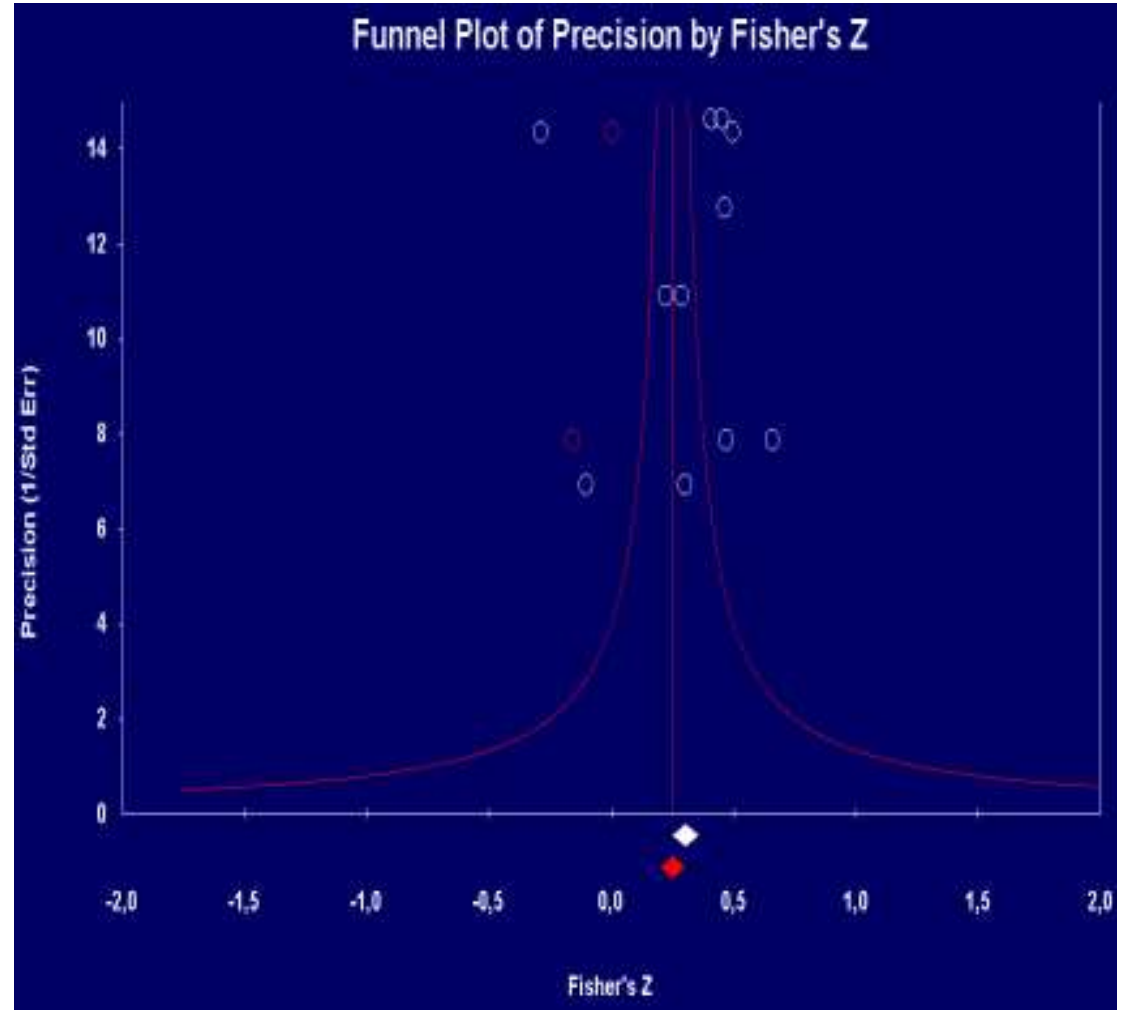

\section{Classic fail-safe $\mathrm{N}$}

Z-latue for coserved studies

P-value for coserved studies

Apha

Tals

$Z$ for abha

Number ol coserved studes

Number of missing studes that would bring p-value to > apha
11,27322

0,00000

0,05000

200000

1,95996

11,00000

353,00000

$\begin{array}{ll}\text { Orwin's fail-safe N } & \\ \text { Fisher's Z in obsened studes } & 0,30358 \\ \text { Cittenon for a trimat isher's z } & 0,00000 \\ \text { Nean fisher's z in missing studies } & 0,00000\end{array}$




\section{$\underline{\text { NOTES }}$}

